\title{
AS BELAS INFIÉIS: LUCIANO NO SALÃO DE M. D'ABLANCOURT ${ }^{1}$
}

Jacyntho Lins Brandão*

Universidade Federal de Minas Gerais

RÉSUMÉ: L'expression "les belles infidèles" a été utilisée par Gilles Ménage pour qualifier la traduction des œuvres complètes de Luciano par Nicolas Perrot, seigneur d'Ablancourt, publiée en 1654 et rééditée à plusieurs reprises depuis 1655 . Il s'agit d'une proposition de traduction qui a incité dès le début, à juste titre, de la controverse. Cet article examine les propositions théoriques de d'Ablancourt et leur utilisation dans ses traductions de Lucien.

MOTS-CLÉS: Lucien de Samosate; traduction; Les belles infidèles; Monsieur d'Ablancourt.

Cexpressão "les belles infidèles" foi utilizada por Gilles Ménage ${ }^{2}$ para qualificar a tradução das obras completas de Luciano por Nicolas Perrot, Senhor d'Ablancourt, publicada em 1654 e reeditada várias vezes a partir de 1655. Trata-se de um trabalho — ou de uma proposta de tradução — que

^jlinsbrandao@ufmg.br

${ }^{1}$ Este trabalho foi apresentado na forma de aula inaugural do Curso de PósGraduação em Tradução da Universidade Federal de Santa Catarina, em 2009. Em 2010, voltei a apresentá-lo, na forma de conferência, nas I Jornadas Internacionales de Estudios Clásicos y Medievales Palimpsestos, da Universidad Nacional del Sur, em Bahía Blanca, Argentina. Esta última versão, em espanhol, mais breve que a presente, foi publicada no mesmo ano, na revista da Asociación Argentina de Estudios Clásicos, Argos (cf. Brandão, 2010).

${ }^{2}$ Ménage nasceu em Angers, em 1613, e faleceu em Paris, em 1692. Escreveu poemas em latim e obras de filosofia, sendo o protótipo de um autor erudito, razão pela qual foi satirizado por Boileau e Molière. 
incitou, desde cedo, a polêmica, tornando-se famoso justamente por isso, como comprova o comentário do quarto Conde Ericeira, D. Francisco Xavier José de Meneses, às primeiras traduções de um texto de Luciano em língua portuguesa, Como se deve escrever a história, devidas às mãos de dois frades jerônimos, Jacintho de São Miguel e Manoel de Santo António, e publicadas num único volume, em Lisboa, em 1733:

O famoso Ablancourt mereceu a antonomásia de atrevido, que algumas vezes é louvor, outras vitupério; mas não perdeu, na tradução das histórias, o nome de tradutor insigne de que se fez digno e que não conservou na versão do mesmo Luciano, a quem chama um bom crítico "o Luciano de Ablancourt".

As "histórias" a que o Conde se refere são as traduções que d'Ablancourt fez de Tácito, César, Tucídides, Arriano e Xenofonte - e essas lhe teriam dado o renome de "tradutor insigne", o que ele não teria conservado ao voltar-se para Luciano. Aliás, o próprio d'Ablancourt afirma, na carta-dedicatória a Monsieur Conrart que abre este último trabalho, ${ }^{4}$ que mudou em Luciano uma série de coisas, "pois trata-se aqui de galanteria e não de erudição". A esse propósito, comenta Bury:

\footnotetext{
${ }^{3}$ Cf. Menezes. Censura das traducçoens da Arte Histórica de Luciano pelo Conde de Ericeira. In: Luciano, 1733, p. $\star \star$ ijj-iiij. O Conde de Ericeira pertencia à Academia Real de História, fundada sob D. João V, de que foi, logo de sua criação, um dos cinco diretores e censores. Nascido em 1673 e falecido em 1743, ele como que encarna o intelectual do tempo, cultivando as matemáticas e as letras, conhecedor de várias línguas, membro de academias nacionais e estrangeiras, correspondente de eruditos da França, Alemanha, Holanda, Itália e Espanha, autor de um número vastíssimo de obras sobre variados assuntos - e, sobretudo, reiteradamente atuando como árbitro em competições poéticas e literárias, ocasiões em que granjeou a fama de imparcial e justo. Estudei as traduções de 1733 em: Como se devem verter os antigos. Nuntius Antiquus, vol. 1, 2007 (www. nuntiusantiquus.ufmg.br); e Luciano, 2009, p. 18-28 (publiquei os prefácios e demais paratextos dessas edições nas p. 101-108).

${ }^{4}$ A carta-dedicatória encontra-se publicada e traduzida por Teresa Dias Carneiro em Faveri e Torres, 2004, p. 48-59.

${ }^{5}$ Cf. D’Ablancourt, in Lucien, 1709, vol. I, p. 7 r. Em todas as citações utilizarei esta edição, de que a Biblioteca Nacional do Rio de Janeiro possui um exemplar, traduzindo os trechos o mais literalmente possível (já que, no nosso caso, não se trata de galanteria); no anexo 1, apresento um extrato do texto na língua original. Os prefácios de d'Ablancourt encontram-se reunidos e comentados em Zuber, 1995.
} 
Mas é verdade (...) que a tradução de Luciano é sobretudo um laboratório da doutrina clássica, que atualiza, a propósito de um sofista do segundo século de nossa era, as principais lições de Guez de Balzac: liberdade em face dos modelos, imitação "adulta" dos antigos, afirmação de um temperamento próprio do escritor. ${ }^{6}$

De início, portanto, retenhamos dois aspectos: o primeiro, que tem atraído em especial a atenção dos estudiosos, de que se trata de um projeto relacionado com as doutrinas clássicas da imitatio e aemulatio; o segundo, que aqui me interessa mais especialmente, de que a tradução de Luciano consiste num "laboratório" dessa doutrina.

Há, portanto, dois aspectos a serem analisados: a) a proposta; b) sua realização efetiva. O que chamo de proposta é desdobrado, nos termos do próprio d'Ablancourt, em "desígnio" (dessein) e "conduta” (conduite), sendo necessário, ainda conforme afirma ele próprio, na carta dedicatória a M. Conrart, começar a obra com respostas às objeções relativas a essas duas ordens de ressalvas, uma vez que "ela encontrará muitos monstros para combater desde seu nascimento", pois "uns dirão que não se deveria traduzir este autor, outros, que se deveria traduzi-lo de outro modo". Como se vê, trata-se de um "desígnio" e de uma "conduta" destinados à polêmica — polêmica que cercou, pelos séculos afora, a recepção do "Luciano de Ablancourt", uma expressão feliz que constrói uma espécie de amálgama identitário entre traduzido e tradutor: nem mais Luciano de Samósata, grego antigo; tampouco Nicolas Perrot d'Ablancourt, francês moderno - mas um novo Luciano d'Ablancourt.

Isso posto, desejo esclarecer que minha intenção não será aqui nem atacar nem defender desígnios e condutas, mas antes, após considerá-los, observar como se efetivam na prática. Confesso que minha primeira opção, nesse sentido, foi dar como subtítulo a este estudo "Luciano na oficina de d'Ablancourt", do mesmo modo que Bury fala de "laboratório". Todavia, tanto "oficina" quanto "laboratório" pareceram-me que soariam muito pesados, daí a solução final: já que se trata de beleza e de infidelidade, "salão" terminou por ser mais expressivo, tanto no sentido clássico dos "salões" literários, quanto no comum de "salões de beleza". No fundo, é neste último tipo de salão que se fazem as "infiéis", através da aplicação de uma certa cosmética capaz de torná-las diferentes de si mesmas, a fim de que se apresentem como se espera nos salões do primeiro tipo, ou seja, "belas"

\footnotetext{
${ }^{6}$ Cf. Bury, 1997.

${ }^{7}$ Cf. D'Ablancourt, in Lucien, 1709, vol. I, p. 3 r.
} 
como convém a determinados espaços e situações. Espartilhos, perucas, ruge, batom, vestimentas: "Os diversos tempos — afirma d'Ablancourt - querem não somente palavras, mas pensamentos diferentes, e os Embaixadores têm o costume de vestir-se na moda do país para onde são enviados, com medo de tornarem-se ridículos para aqueles que eles procuram agradar". ${ }^{8}$ Uma operação, portanto, que, tomando um certo corpo como base - e, neste caso, um corpus antigo - moderniza-o, isto é: trabalha no sentido de que se apresente à la mode.

Eu afirmei que não é minha intenção defender nem atacar as "belas infieis", pois sua apreciação depende também de mudanças do gosto estético. Eu diria que nossa época é mais propícia a apreciá-las: SeligmannSilva considera mesmo que se trata da "essência da tradução", uma vez que "toda tradução parte da separação entre o significante e o significado"; mas já seu contemporâneo Tallemant, após observar que d'Ablancourt é "um gênio como Montaigne, mas mais regrado", e que, por indolência, não produziu nada que fosse de sua própria autoria, dedicando-se inteiramente às traduções, acrescenta que, com relação a estas, é preciso admitir que "ele tinha razão", já que se lêem "como originais"; ${ }^{10}$ na mesma linha segue o Abade Longuerue, ao declarar que d'Ablancourt e Patru são "dois mestres de estilo e, depois da morte do primeiro, a língua, longe de aperfeiçoar-se, não fez mais que declinar", acrescentando que "há muito que aproveitar" no seu Luciano, já que ele "transmite as belezas particulares da língua grega e certas locuções através de outras que produzem o mesmo efeito em nossa língua". "Essa perspectiva não se distancia muito da percepção atual relativa

\footnotetext{
${ }^{8}$ Cf. D'Ablancourt, in Lucien, 1709, vol. I, p. 7 v.

${ }^{9}$ Cf. Seligmann-Silva, 2004, p. 260.

${ }^{10}$ Cf. Tallemant, 1858: D'Ablancourt, dit Tallemant, est un esprit comme Montaigne, mais plus reglée: il s'est amusé par paresse aux traductions et n'a rien produit de luy-mesme, que la préface de l' "Honneste fermme». (...) Je ne parlerai pas icy de ses traductions ny des libertez qu'il s'y donne. Il faut bien qu'il ayt raison, puisqu'on lit ses traductions comme des originaux. (...) J'oubliois de dire qu'il copie jusqu'à cinq fois ses ouvrages. C'est un garçon d'honneur et de vertu, et le plus humain qu'on sauroit trouver. Gédéon Tallemant des Réaux nasceu em La Rochelle em 1619, falecendo em Paris, em 1692.

${ }^{11}$ Cf. Longuerue, 1858: D'Ablancourt et Patru, dit l'abbé Longuerue, sont les deux maitres pour le style, et depuis la mort du premier, la langue, loin de se perfectionner, n'a fait que décliner. (...) Il y a beaucoup à profiter dans son Lucien: je me suis toujours étonné comment d'Ablancourt a traduit son "Cratès»: il y a fait des grands changements, j'en conviens, mais il n'est pas possible d'en faire quelque chose de bon. Le plus parfait de tous les ouvrages de d'Ablancourt, c'est son Thucydide, soit dans les harangues, soit dans les récits; son Lucien est excellent en ce qu'il rend les beautés particulières à la langue grecque, et certaines locutions
} 
à própria literatura. Em entrevista recente, Casa Nova, interrogada por um repórter sobre "o que há de novo no campo das artes literárias”, respondeu:

Novo não existe nada. O novo é uma ilusão. Tudo já foi dito, tudo já foi feito, o que a gente faz contemporaneamente é dar uma outra roupagem. Aí sim você tem novas relações. E com um suporte diferente se criam propostas diferentes. Não é a palavra novo que tem que ser dita, mas sim a palavra diferença. ${ }^{12}$

No fundo, essa poderia ser uma definição adequada de tradução: o mesmo em roupagem diferente — o que nos traz de volta à roupa nova que envolve corpos já ditos. Tendo em vista essa contextualização mínima, passo agora a explorar a proposta de d'Ablancourt, em seus desígnios e condutas, para, em seguida, observarmos o que se passa com Luciano em seu salão.

\section{Desígnios: o que traduzir}

Desígnios dizem respeito à escolha do que traduzir. Nesse sentido, as considerações de d'Ablancourt, no campo de esperada polêmica, visam a responder à crítica, por ele prevista da parte de alguns, de que "não se deveria traduzir este autor", com base nos argumentos de que Luciano é um libertino (libertin) e, com o que d'Ablancourt também concorda, "um pouco grosseiro nas coisas do amor, o que é marca de um espírito antes debochado que galante". Mais apenas que uma tirada retórica, devemos considerar que esse primeiro movimento tem certamente consequências práticas, pois inclui a avaliação das qualidades e defeitos do corpus escolhido, levando à adoção de determinadas condutas.

Além de resumir os dados da "vida" de Luciano tradicionalmente retirados de suas obras e de rebater algumas críticas de que ele era alvo a principal das quais o acusava de haver zombado dos primeiros cristãos - ${ }^{13}$ d'Ablancourt arrola como motivos para sua escolha o seguinte: a)

par d'autres qui font le même effet en notre langue.

${ }^{12}$ Cf. Casa Nova, 2009.

${ }^{13}$ Assim, por exemplo, o fato, já sublinhado pela Suda, de que teria atacado os cristãos e blasfemado contra o próprio Cristo: Luciano, samosatense, o chamado blasfemo ou difamador - ou ateu, para dizer mais -, porque, em seus diálogos, atribuiu ser risível até o que se diz sobre as divindades. Era, de início, advogado em Antioquia, na Síria, mas, não tendo tido sucesso, voltou-se para a logografia e escreveu infindáveis obras. Diz-se ter sido morto por cães, posto que foi contaminado pela raiva contra a verdade, pois, na vida de Peregrino, o infame atacou o cristianismo e blasfemou contra o próprio Cristo. Por isso, também pagou, com a raiva, a pena devida neste mundo e, no futuro, sua herança será o 
Luciano é um dos mais belos gênios (Esprits) de sua época; b) cultiva a "urbanidade ática", fazendo uso de uma zombaria (raillerie) fina e delicada, e adotando um estilo simples, puro, elegante e polido; c) ele põe à mostra a futilidade e impostura dos deuses gregos, o orgulho e ignorância dos filósofos, a debilidade e inconstância das coisas humanas; ${ }^{14}$ d) com sua zombaria, insinua-se com doçura nos espíritos e transmite uma moral útil e agradável; e) com ele podem-se aprender mil coisas, pois sua obra apresenta um "buquê de flores" do que há de mais belo nos antigos; f) ele trata as fábulas de modo engenhoso e, assim, contribui para o entendimento dos poetas; g) prova de suas qualidades é que sua obra se conservou, apesar da pouca afeição dedicada a seu autor e ao naufrágio de tantas peças da Antiguidade que se perderam; h) enfim, ela conheceu muitas traduções, especialmente para a língua latina. Cumpre ressaltar este último argumento, pois, de fato, desde 1470 , com as primeiras traduções para o

fogo eterno, na companhia de Satanás (Suidae Lexicon, L 683 Adler). A isso contrapõe d'Ablancourt: Suidas veut qu'il ait esté déchiré par les chiens, mais c'est aparemment une calomnie pour venger de ce qu'il n'a pas épargné dans ses railleries les premiers Chrestiens non plus que les autres: Toutefois, ce qu'il en dit se peut raporter, à mon avis, à leur charité $\mathcal{E}$ à leur simplicité, qui est plutôt une loüange qu'une injurie; joint qu'on ne doit pas attendre d'un Payen, l'éloge du Christianisme (D'Ablancourt, in Lucien, 1709, vol. I, p. 4 v.).

${ }^{14}$ Percebe-se que esses primeiros argumentos ressoam as considerações do patriarca Fócio (autor provavelmente lido pelo erudito d'Ablancourt): Lido de Luciano o texto sobre Faláris e diferentes diálogos dos mortos e das prostitutas, além de outros livros sobre diferentes assuntos, nos quais, em quase todos, faz comédia dos costumes dos gregos, tanto do erro e da loucura de sua fabricação dos deuses, quanto de sua irresistivel tendência para a intemperança e a impudência, as estranhas opiniões e ficções de seus poetas, a decorrente errância de sua organização política, o curso anômalo e as vicissitudes do resto de suas vidas, o caráter jactancioso de seus filósofos, pleno nada mais que de hipocrisia e vãs opiniões. Em suma, como dissemos, sua ocupação é fazer, em prosa, comédia dos gregos. Parece ser dos que não respeitam absolutamente nada, pois, fazendo comédia e brincando com as crenças alheias, ele próprio não define a que honra, a não ser que alguém diga que sua crença é em nada crer. Todavia, sua expressão é excelente: faz ele uso de um estilo distinto, corrente e enfaticamente brilhante, mais que nenhum outro ele ama a claridade e a pureza, associadas a brilho e grandeza proporcionada. Sua composição é tão harmoniosa que parece, ao que o lê, que ele não diz palavras - mas uma certa melodia agradável, sem canto aparente para os ouvidos, saboreiam os ouvintes. Em resumo, como dissemos, seu discurso é excelente, mas não convém aos argumentos com os quais ele mesmo sabe que brinca, ridicularizando-os. Que ele próprio é dos que não creem em absolutamente nada, a epígrafe de seu livro dá a entender, pois diz assim: Eu, Luciano, isto escrevi, coisas antigas e estúpidas sabendo,/ pois estúpido é tudo para os homens, até o que parece sábio./ Entre os homens não há, em absoluto, nenhuma inteligência,/ mas, o que admiras, isso para outros é risível (Fócio, Biblioteca 128). 
latim, iniciou-se uma tradição de traduções de Luciano - e a denomino tradição porque os sucessivos tradutores consideraram, em geral, os trabalhos anteriormente aparecidos, alguns mesmo, como Baudoin com relação a seu antecessor Bretin, em certa medida não mais que remanejando traduções pré-existentes. $^{15}$

${ }^{15} \mathrm{Na}$ Antiguidade, tem-se notícia de uma tradução de Luciano para o siríaco (aramaico). A partir do Renascimento, até a publicação do trabalho de d'Ablancourt, registram-se as seguintes traduções (não havendo nenhuma outra indicação, trata-se das obras completas ou da reunião de várias obras): Roma, 1470, Tyrannus, Vitarum auctio, tradução latina de Christophore Persona (?); Roma, 1470, Charon, Timon etc., trad. latinas por Rinuccio, Bertoldo, Persona; Augsburgo, 1477, Asinus, trad. latina de L. von Hohenwang; Bruges, 1475, Le débat... des trois princes (dos diálogos dos mortos), trad. francesa de Jean Miélot; Veneza, 1494, De veris narrationibus, contendo vários textos, em traduções latinas, de autoria variada (reeditada várias vezes); Paris, 1506, dezesseis opúsculos traduzidos em latim por Erasmo de Roterdam e Thomas Morus; Ferrara, 1510, Judicium vocalium, edição bilíngue, com tradução latina de Coelio Calcagnini; Strasburgo, 1517, com quatro opúsculos em trad. latinas de Erasmo, Luscinius e N. Bérault; Louvain, 1519, Icaromenippus, Necromantia, trad. latinas de Erasmo, Morus e Bérault; Wittemberg, 1519, Adv. Calumniam, texto grego e trad. latina de P. Melanchthon; Paris, 1521, D. mort., De luctu, trad. latinas de Rinuccio e Erasmo; Bâle, 1522, Tyrannicida e Abdicatus, texto grego e tradução latina de Erasmo de Roterdam; Veneza, 1525, Dialoghi di Luciano, tradução italiana de Nicolas de Lonigo; Paris, 1527, Calumnia, $A d v$. Indoctum, trad. latina do primeiro por Melanchthon; Viena, 1527, nove opúsculos traduzidos em latim por J. A. Brassicanus; Haguenau, 1529, vários textos traduzidos em latim por Vicent Obsopoeus; Paris, 1529, Trente dialogues moraux de Lucian, trad. francesa de Geoffroy Tory; Paris, 1532, Le Jugement de Minos (dos diálogos dos mortos), trad. francesa de J. Miélot; Haguenau, 1533, Enconium Demosthenis, trad. latina de Melanchthon; Frankfurt, 1538, primeira tradução da obra completa de Luciano, com textos latinos de autoria variada, apresentados por Jacques Micylle (pseudônimo de Möltzer de Strasbourg), ele próprio traduzindo várias peças e retomando traduções de Erasmo, More, Melanchthon etc.; Frankfurt, 1546, edição bilíngue grego-latim (não se conhece mais nenhum exemplar dessa edição); Bâle, 1563, edição bilíngue grego-latim, com traduções tomadas da edição de Frankfurt, 1538 (republicada em Bâle, 1602 e 1619); Paris, 1572-3, Devis des dieux pris de Lucien (nove diálogos dos deuses), trad. francesa por Jean-Antoine de Baif; Genebra, 1574, Bis accusatus, texto grego por Henri Estienne e trad. latina de J. Micyllus (tomada da de Frankfurt, 1538); Paris, 1581, Les oeuvres de Luc. de Sam. Philosophe excellent, non moins utiles que plaisantes..., répurgées de paroles impudiques et profanes qui sont réduites en propos plus honnêtes, primeira tradução francesa completa, por Philibert Bretin; Paris, 1613, Oeuvres completes, trad. francesa de Jean Baudoin (ele retoma em grande parte a tradução de Bretin, de 1581); Paris, 1615, texto 
Como se vê, os argumentos de d'Ablancourt para justificar seu desígnio ressaltam qualidades que fazem de Luciano uma figura digna dos salóes seiscentistas (espirituoso, urbano, zombeteiro, fino, delicado, de estilo simples, puro, elegante e polido); de outro, o proveito e a utilidade que a leitura de sua obra provê (ensinamento moral e sobre os antigos, inteligência dos poetas). Recorde-se que não se trata de defender Luciano contra os que o criticam, mas de defender que se o traduza contra os que acreditam que não se deveria fazê-lo. Por isso importa apresentar um Luciano que, ainda que apresente defeitos, nada fica a dever aos gentis-homens de então.

\section{Condutas: como traduzir}

Esse tópico das justificativas de d'Ablancourt referidas na cartadedicatória visa a responder à possível objeção de que, admitindo-se que Luciano seja digno de ser traduzido, deveria tê-lo sido de outro modo (autrement). Nesse âmbito, distingo dois aspectos: a) as assertivas de ordem mais geral (ou teórica), que funcionam como verdadeira declaração de princípios relativos à tradução - e que, em geral, atraem mais a atenção dos comentadores; b) as operações através das quais d'Ablancourt afirma ter posto em prática os princípios - as quais nos guiarão para, no passo seguinte, examinar e avaliar, através de alguns exemplos, os resultados.

\section{Princípios gerais: o possível, o impossível, o além do (im) possível}

O primeiro pressuposto é que, na tradução, muitas coisas devem ser mudadas, para fazer-se algo agradável, pois de outro modo não mais seria Luciano. Há duas razões: a) o que agrada na língua dele não seria suportável (suportable) na nossa; b) e, quando o único objetivo de um autor é o prazer (plaisir), como acontece com Luciano, então não se pode tolerar o menor defeito (defaut), pois, por pouco que falte delicadeza (delicatesse), o leitor se aborrecerá, em vez de se divertir. Assim, o que importa é preservar

grego por Jean Bourdelot e trad. latinas doctissimorum virorum, sobretudo os que se encontram na tradução de Frankfurt, 1538 e 1543, além de uma nova tradução do próprio Bourdelot; Saumur, 1619, texto grego por Jean Benedictus e trad. latina em grande parte nova; Oxford, 1634, seleção de obras traduzidas em inglês por Fr. Hickes; Leiden, 1652, Timon, texto grego e a tradução latina de Erasmo, revista; Paris, 1653, De morte Peregrini, edição grego-latim, sem indicação do tradutor; Paris, 1654, obra completa trad. em francês por N. Perrot d'Ablancourt (cf. Bompaire, 1993, p. CXXIV-CL). 
o objetivo (but) do autor, a que tudo mais deve ser sacrificado: "Não me ato sempre — afirma d'Ablancourt — às palavras (paroles) nem aos pensamentos (pensées) deste autor; preservando seu objetivo (but), disponho (j'agence) as coisas de acordo com nosso modo de ser (à nôtre air) e nossa maneira (à nôtre façon)". ${ }^{16}$

Como se vê, uma declaração bastante radical: é lugar comum dizer-se que, numa tradução, se pode optar por não se prender às palavras, expressões e frases do texto de partida, optando-se por traduzir o pensamento do autor; ${ }^{17}$ d'Ablancourt, contudo, em nome de um princípio que considera mais alto, o objetivo, dá-se a liberdade de não atar-se nem a palavras, nem a pensamentos. Se, ainda de acordo com a terminologia comum, a tradução que se ata às palavras se costuma chamar de literal e a que se ata não àquelas, mas aos pensamentos, de livre, d'Ablancourt defende a existência de um terceiro nível, que ele admite não ser "propriamente tradução", mas valer "mais que a tradução" (cela vaut mieux que la Traduction), algo para o que não encontra um nome, não importando isso, desde que se tenha a coisa (mais il n'importe du nom, pourvu que nous ayons la chose). A “coisa”, neste caso, se encontra na prática dos antigos: "Assim é que Terêncio fez nas comédias, que tomou de Menandro, ainda que Aulo Gélio não as deixa de chamar de traduções"; do mesmo modo, Cícero, cujos Ofícios "não são quase mais que uma versão de Panécio", afirma, nas traduções que fez das Orações de Demóstenes e de Ésquines, que "trabalhou não como intérprete, mas como orador". ${ }^{18}$ Talvez, a partir das sugestões que emanam desses exemplos, pudéssemos então chamar o que não tem nome de tradução autoral, aquela que tem em vista não palavras ou pensamentos do texto de partida, mas sua intenção (but), de tal modo que se possam ler, nos termos de Tallemant, "como originais".

Dizer "como", neste caso, é importante, porque de fato não se trata de originais, desenhando-se assim uma zona cinzenta de fronteira entre

\footnotetext{
${ }^{16}$ Cf. D'Ablancourt, in Lucien, 1709, vol. I, p. 7 r.-7 v.

${ }^{17} \mathrm{Na}$ disputa oitocentista entre os dois frades portugueses que publicam uma tradução de Como se deve escrever a história, Frei Jacintho de São Miguel assim descreve a diferença entre as duas opções: O referido Padre [Manoel de Santo António] verteu do original a sentença, sem ater-se às palavras, procurando com todas suas forças manifestar o pensamento do autor com as próprias frases da língua portuguesa que mais se assemelhassem às expressões da língua grega. Eu, de maneira me sujeitei e me quis atar às palavras e às frases gregas, que até os casos dos nomes, os tempos, os modos e as vozes dos verbos trabalhei por exprimir, quanto pude, na língua portuguesa. Esta vem, pois, a ser a controvérsia: qual das duas versões pode ler-se sem deslustre do tradutor (São Miguel, 1733. Negritos meus).

${ }^{18}$ Cf. D’Ablancourt, in Lucien, 1709, vol. I, p. 7 v.
} 
a produção propriamente dita e a tradução. Seria um erro pensar que d'Ablancourt defenda a tradução autoral tout court, pois diz ele apelar para ela apenas quando não se pode adotar a tradução literal ou livre: assim, com relação às palavras, declara que "não me dei a mesma liberdade em toda parte e há muitas passagens traduzidas palavra por palavra (traduits de mot à mot), pelo menos na medida em que se podia fazer numa tradução elegante" (Traduction élegante); por outro lado, com relação aos pensamentos, assevera que "deixei-lhe [a Luciano] inteiramente suas opiniões, porque de outro modo não seria uma tradução”. Desse modo, em vez de entender que se advoga a favor de um determinado tipo de tradução, acredito que d'Ablancourt se move no contexto bastante prático das possibilidades com que lida o tradutor. Dizendo de outro modo, antes que uma profissão de fé, trata-se de reconhecer uma escala: quando possível, a tradução mot à mot é a preferível, desde que não sacrifique a elegância; num segundo nível de possibilidades, é preciso preservar as opiniões do autor, caso contrário não se teria uma tradução; em seguida, para que não se perca seu objetivo (but), então resta a tradução autoral. Passado esse limite, adentra-se o terreno da impossibilidade, uma ideia preciosa defendida por ele: há o que se pode traduzir, de acordo com a escala acima, e o intraduzível. No caso de seu Luciano, d'Ablancourt reconhece que "há mesmo peças que não se pôde absolutamente traduzir, como a do Julgamento das vogais e duas ou três outras semelhantes, que consistem na propriedade de termos gregos e não seriam entendidas fora dessa esfera”. O limite da tradução seria o dessa impossibilidade - o que conduz ao âmbito em que, deixando de ser tradução, o texto produzido já se apresenta como autêntica criação (se quisermos: recriação) literária, como os de Terêncio, Plauto e Cícero, que, apesar de chamados de tradução, são mais que tradução.

Considero importante insistir nisso, para que não se fique com a impressão de que as "belas infiéis" ultrapassaram os limites da tradução e é em vista disso que se definem — ou por isso que são belas. Vale lembrar que d'Ablancourt dedicou sua atividade intelectual inteiramente às traduções e se teve sempre por tradutor. Se é verdade que ele declara sua proximidade com Cícero, o qual, vertendo oradores gregos, "trabalhou não como intérprete, mas como orador", faz alguma ressalva, que convém frisar:

[Cícero] diz que trabalhou não como intérprete, mas como orador, o que é a mesma coisa que tenho a dizer dos diálogos de Luciano, embora não me tenha dado uma igual liberdade em todos os pontos (quoy que je ne me sois donné une égale liberté par tout). Há muitas passagens que traduzi palavra por palavra, pelo menos o quanto se 
pode fazer numa tradução elegante... ${ }^{19}$

Dado, portanto, o critério - uma tradução elegante que não faça com que Luciano deixe de ser Luciano - , lida-se é com graus de possibilidade, do mais possível até o impossível, esta última esfera merecendo um tipo de tratamento adequado.

Mas existe também, do lado oposto, um outro limite extremo: o das "traduções escrupulosas" (Traductions scrupuleuses), defendidas pelos "idólatras de todas as palavras e de todos os pensamentos dos antigos" (idolâtres de toutes les paroles \& de toutes les pensées des Anciens). Vale a pena reproduzir, na íntegra, o trecho a elas referente, partindo de onde deixamos as considerações anteriores:

Há também muitas passagens que traduzi palavra por palavra, pelo menos o quanto se pode fazer numa tradução elegante. Há também outras em que considerei sobretudo o que se deveria dizer, ou o que eu podia dizer que ele [Luciano] havia dito, a exemplo de Virgílio no que tomou de Homero e de Teócrito. Mas me contive em quase todos os lugares, sem descer ao particular, que não é mais deste tempo. Todavia, sei bem que isso não agradará a todo mundo e principalmente àqueles que são idólatras de todas as palavras e de todos os pensamentos dos antigos - e que não creem que seja boa uma obra cujo autor ainda viva. Pois esse tipo de gente gritará como fazia no tempo de Terêncio: Contaminari non decere fabulas, que não se devia absolutamente corromper seu autor, nem nada alterar de seu assunto. Mas eu lhes responderia, com ele:

Faciuntne intelligendo, ut nihil intelligant, Qui cum hunc accusant, Naevium, Plautum, Ennium Accusant, quos hic noster authores habet [p. 8 v.] Quorum aemulari exoptat negligentiam Potius, quam istorum obscuram diligentiam. ${ }^{20}$

Que essa obscuram diligentiam expressa bem o defeito dessas traduções escrupulosas, das quais é preciso ler o original para entender a versão. ${ }^{21}$

\footnotetext{
${ }^{19}$ Cf. D'Ablancourt, in Lucien, 1709, vol. I, p. 7 v.-8 r.

${ }^{20}$ Terêncio, Ândria 16-21: "Não se deve corromper a fábula./ Fazem de entendidos - e nada entendem -,/ Pois os que acusam a este, a Névio, Plauto e Ênio/ Acusam, a quem o nosso [poeta] tem por mestres./ Mais vale destes emular a negligência,/ Que a daqueles obscura diligência”.

${ }^{21}$ Cf. D’Ablancourt, in Lucien, 1709, vol. I, p. 8 r.-8 v. Os versos citados são assim parafraseados por d'Ablancourt, em nota posta do lado direito da página: "Eles
} 
Volto a insistir que, mais que princípios, o que se explicita deriva da prática de traduzir: entre os dois extremos, "o que não é mais tradução, mas vale mais que a tradução", e as "traduções escrupulosas", que, no fundo, também não são tradução por ser "preciso ler o original para entender a versão", é que se situam as "belas infiéis". Do lado dos escrupulosos, poderíamos dizer que a fidelidade sacrifica a beleza, o que terminaria por implicar uma outra espécie de infidelidade, ao objetivo (but) do texto; no outro extremo, à beleza se sacrifica qualquer tipo de fidelidade, aliás, o laço de fidelidade se rompe, já que se ultrapassou o limite do que seria uma tradução. Dito de outro modo: a "bela infiel" só pode ser infiel porque não se divorcia de seu referente (o original), mas, mantendo intocado o relacionamento, apenas trai aqui e acolá, em nome de algo que considera maior que a fidelidade: o amor da beleza.

Saber como, quando e por que se deve trair passa a ser, assim, nosso próximo objeto de investigação.

\section{Operações tradutológicas}

Minha intenção agora é entrar no espaço interno do salão de d'Ablancourt, para nos inteirarmos das operações a que se submetem as infiéis, visando a tornarem-se belas - ou, noutros termos, continuando a ter em conta as declarações da carta-dedicatória, pretendo extrair dela e, na medida do possível, classificar as operações tradutológicas que d'Ablancourt afirma ter posto em prática. Essas são expressas por uma série de verbos, a saber: a) cortar; b) suavizar; c) mudar; d) retocar; e) esclarecer; f) dispor aos quais acrescento mais um, a saber: expandir. Entre dois extremos (cortar e expandir), uma série de operações cosméticas destinadas a preservar-se o objetivo (but) do autor numa tradução elegante.

É importante salientar que, mesmo no que diz respeito à expansão, de todas a mais ousada, todas essas são operações que se efetivam no original, com o qual, portanto, nunca se rompem as relações (garantia última tanto da fidelidade, quanto da infidelidade). Da perspectiva de d'Ablancourt, todas são operações legítimas, cabendo ao tradutor o discernimento de onde aplicá-las no corpus com que lida (e seria uma falta imperdoável aplicar a cosmética num lugar inadequado, o que produziria um efeito inverso ao esperado).

Assim, ele esclarece:

perdem a razão à força de raciocinar. Pois, acusando-o, acusam os antigos que ele tem como fiadores e dos quais ele prefere imitar a negligência mais que a obscura exatidão dos outros". 
a) ter cortado (j'ay retranché) o que havia de mais sujo — ordinário, desagradável (sale) $;^{22}$

b) ter adoçado (j'adoucy) em algumas partes o que era muito livre (trop libre) — já que Luciano é um libertino (libertin); ${ }^{23}$

c) ter sido necessário mudar (il a falu changer) o seguinte: i. o que provocaria horror a nossos contemporâneos (ferroit horreur aux nôtres), como tudo o que se refere à pederastia grega; ii. o que agora seria entendido como pedantismo (pedanteries), como as referências constantes a versos de Homero; iii. o muito batido, no caso dos entrechos (vieilles Fables trop rebatües); iv. o envelhecido (suranné) em termos de provérbios, exemplos e comparações; ${ }^{24}$

d) ter sido preciso retocar (retoucher) os menores defeitos, que existem mesmo nos melhores autores, como nos belos rostos - o que parece dizer respeito ao estilo; ${ }^{25}$

e) ter sido preciso esclarecer (éclaircir) as menores obscuridades, que igualmente se encontram nos melhores autores, como nos belos semblantes - o que provavelmente concerne aos pensamentos; ${ }^{26}$

d) ter disposto as coisas de acordo com nosso modo de ser e a nossa maneira (j'agence les choses à nôtre air et à nôtre façon), como fazem os embaixadores ao mudar de roupa, sem me atar às palavras e aos pensamentos do autor, a fim de preservar seu objetivo $($ but $) ;^{27}$

e) finalmente, o que não d'Ablancourt, mas eu próprio denominei de expandir, quando finalmente o tradutor se aventura a dizer o que o autor "deveria dizer", uma sorte de coroamento das operações anteriores, pois se trata de, em certa medida, compartilhar a própria autoria, nos limites extremos do que já não seria tradução, embora valha mais que traduções. ${ }^{28}$

Além dessas operações que atuam no interior do texto, é preciso registrar ainda mais uma, de ordem paratextual, ou seja, responder: já que é preciso conservar inteiramente as opiniões (opinions) do autor, afirma d'Ablancourt, "respondo, no argumento e nas observações, ao que há de mais forte (ce qu'il $y$ a de plus fort), a fim de que isso não possa causar

\footnotetext{
${ }^{22}$ Cf. D’Ablancourt, in Lucien, 1709, vol. I, p. 6 v.

${ }^{23}$ Cf. D’Ablancourt, in Lucien, 1709, vol. I, p. 6 v.

${ }^{24}$ Cf. D'Ablancourt, in Lucien, 1709, vol. I, p. 7 r.

${ }^{25}$ Cf. D'Ablancourt, in Lucien, 1709, vol. I, p. 7 r.

${ }^{26}$ Cf. D'Ablancourt, in Lucien, 1709, vol. I, p. 7 r.

${ }^{27}$ Cf. D’Ablancourt, in Lucien, 1709, vol. I, p. 7 v.

${ }^{28}$ Cf. D'Ablancourt, in Lucien, 1709, vol. I, p. 8 r.
} 
prejuízo (nuire). ${ }^{29}$

\section{As práticas do salão (1): traduzir o traduzível}

Passemos agora a examinar, através de alguns exemplos, como se pratica o receituário do salão de d'Ablancourt. Para tanto, além do texto grego de Luciano, lançarei mão de outras traduções para a língua portuguesa, minhas e de outros, a fim de dar a perceber as operações próprias da "bela infiel". Em especial, com relação a alguns casos, apresentarei também a tradução de Jean Baudoin, ${ }^{30}$ uma vez que ele é considerado, ao lado de Jacques Amyot, um dos mais destacados representantes da "idade de ouro da tradução concebida como obra literária”, da qual d'Ablancourt constitui o "apogeu" e a "consagração". 31

Como se viu, d'Ablancourt afirma ser um tradutor de Luciano menos censurável (blâmable) que outros, uma vez que sustenta ter "cort[ado] o que havia de mais sujo" (j'ay retranché ce qu'il y avoit de plus sale), operação que parece ter um endereço certo: as passagens com conteúdo sexual. ${ }^{32}$ Ele mesmo comenta que, apesar de todas as qualidades, considera Luciano

um pouco grosseiro nas coisas do amor (un peut grossier, dans les choses de l'Amour), seja que isso se deva imputar ao espírito de seu tempo ou ao seu, mas, quando ele quer falar disso, sai dos limites da educação (bornes de l'honêteté) e cai incontinenti na sujeira (sale), o que é antes marca de um espírito debochado que galante. ${ }^{33}$

Neste caso, portanto, trata-se de uma operação radical, pois consiste em eliminar do corpus as imperfeições que ele apresenta.

Um exemplo bastante significativo desse procedimento encontramos na cena de sexo entre o protagonista de Lúcio ou o asno e a jovem Palestra (cujo nome significa, em grego, luta). ${ }^{34}$ Trata-se de um entrecho difícil

${ }^{29}$ Cf. D'Ablancourt, in Lucien, 1709, vol. I, p. 6 v.-7 r.

${ }^{30}$ Lucian de Samosate, 1613.

${ }^{31}$ Cf. Bury, 1997, p. 362: À l'autre extrémité, Perrot d'Ablancourt, qui a connu et illustré l'apogée du genre' (R. Zuber) et sa reussite institutionelle consacrée par l'Académie (1635)...

${ }^{32}$ A primeira tradução completa do corpus luciânico para o francês, devida a Philibert Bretin e aparecida em Paris, em 1581, já cuidava de expurgá-lo "de palavras impudicas e profanas, que são vertidas em proposições mais honestas" (répurgées de paroles impudiques et profanes qui sont réduites en propos plus honnêtes).

${ }^{33}$ D'Ablancourt, in Lucien, 1709, vol. I, p. 5 v.

${ }^{34}$ No anexo 2 infra, encontram-se os textos comentados. 
de traduzir, pelo jogo entre o nome da jovem serva, Palaístra, e o sentido comum do termo: o lugar onde se treina para a luta, ${ }^{35}$ o lugar onde se praticam exercícios em geral, a escola. ${ }^{36}$ Daí a cena tira seu sentido: Palestra sendo luta, exerce ela também a função da mestra (didáskalos) que ensina ao aluno (mathetés) os golpes adequados, utilizando uma terminologia técnica nessa esfera. Como se transporta tudo para o campo sexual, nisso está o cômico, na exploração dos duplos sentidos que perpassam toda sua fala:

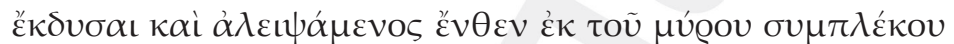

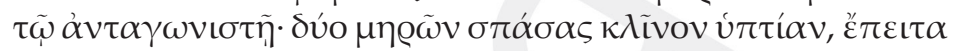

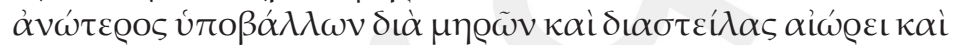

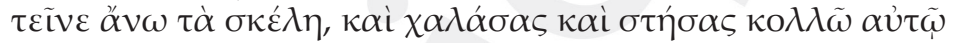

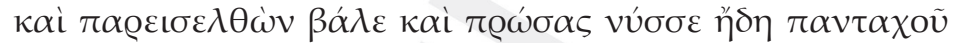

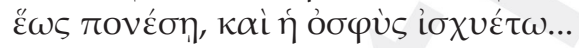

despe-te e perfuma-te com esta loção e abraça a tua antagonista; agora puxa-a pelas duas pernas, e deita-a de costas; a seguir, e por cima dela, mete-lhe as pernas por entre as coxas, afasta-as, mantém as pernas elevadas e esticadas; depois, deixa-as descair e, com firmeza, cola-te a ela, penetra, ataca, avança, entra já a matar, à queima-roupa, até que ela fique derreada; força nesses rins!... ${ }^{37}$

Baudoin não se furtou a traduzir o trecho, vertendo inclusive, desde o início, o nome de Palaistra como Lutte, o que resolve um problema que d'Ablancourt solucionou através de uma nota. Radical, entretanto, foi a decisão deste último no que concerne à descrição detalhada da "luta": ele simplesmente a elimina, alertando contudo o leitor, noutra nota, que "há aqui uma passagem suja suprimida" (Il y a ici un passage de saletez retranchée). Assim, o trecho em que parece que Luciano teve prazer em alongar-se, foi vertido assim por d'Ablancourt:

Como aceitei o combate, ela se despe, e me diz que o campo estava aberto a meu valor. Após alguns torneios de esgrima, em que cada

\footnotetext{
${ }^{35}$ Cf. Heródoto 6, 126; Eurípides, Electra 528.

${ }^{36}$ Cf. Xenofonte, República dos lacedemônios 2, 1; Pseudo-Longino 4, 4.

${ }^{37}$ Lúcio ou o asno 9 (tradução de Magueijo). O trecho completo dessa primeira "luta" e o confronto de várias traduções encontra-se no anexo 2.
} 
um tratou de mostrar o que sabia fazer, deixamos o resto para o dia seguinte" (Comme j' eus accepté le combat, elle se deshabille, E me dit que le champ estoit ouvert à ma valeur. Après quelques tours d'escrime, où chacun tâcha de montrer ce qu'il sçavoit faire, nous remîmes la partie au lendemain.).

O ponto de sutura aproveitou entrecho da segunda parte da luta entre Palestra e Lúcio, na qual a jovem ordena: "Vamos, lutador, aqui tens a arena: brande a arma em riste, avança, entra a fundo!" — ${ }^{38}$ terminando a rodada de exercícios com a declaração de Lúcio de que eles haviam continuado, por várias noites, esses jogos, "a ponto de eu me esquecer completamente da minha viagem a Larissa".

É importante observar como, efetuado o corte, procede-se à sutura: a) no primeiro movimento, mantêm-se, como em Luciano, o jantar, os brindes, os beijos - e adianta-se o gozo das "primícias do amor"; b) mantém-se parte da fala de Palestra em discurso direto, mas eliminando-se toda referência à relação mestra-discípulo; c) no breve e discreto aceno à cena de sexo, que marca o início e o fim da passagem suprimida (elle se deshabille, E me dit que le champ estoit ouvert à ma valeur. Après quelques tours d'escrime...), é significativo que os dois amantes se mostrem em pé de igualdade - mostrando o que cada um sabia fazer - e que a luta tenha sido mudada para esgrima, o que não deixa de tornar à la mode o efeito pretendido por Luciano.

A referência à esgrima aponta para outra operação: adoucyr (adoçar, abrandar). De fato, a remissão a espadas sugere, de um modo elegante, uma conotação fálica: Luciano, como vimos, oferece a sugestão, ao fazer Palestra dizer: tináxas oxeîan, literalmente, levantando [a arma] aguda, o que leva a que Baudoin fale de "dardo" na sua tradução:

"Vamos, deita-me de bruços, sobe em cima, e enquanto eu levantar as coxas, apoia-te sobre elas; depois bate de todas as partes, e lança teu dardo até que estejas cansado, e que teus rins tenham posto fim a um tão belo exercício" (Sus, couche moy à l' envers, gaigne le dessus, $\mathcal{E}$ tandis que ie leueray les cuisses, appuye toy sur elles; puis frappe de toutes parts, E lance ton dard iusqu' à ce que tu sois las, E que tes reins ayent mis fin à un si bel exercice.).

$\mathrm{Na}$ mesma linha de passagem entre cortar e adoçar parece-me que se pode incluir também outro passo de Lúcio, quando, já transformado em asno, uma mulher se apaixona carnalmente pelo protagonista.

\footnotetext{
${ }^{38}$ Lúcio ou o asno 10.

${ }^{39}$ Lúcio ou o asno 11.
} 
D’Ablancourt, neste caso, eliminou as partes mais descritivas do sexo, sem nenhuma advertência ao leitor, ainda que tenha mantido o entrecho de zoofilia - o que nos garante que não há assuntos que sejam em si mesmos sales, mas qualquer tema pode ser tratado com elegância. ${ }^{40}$ Os procedimentos podem ser resumidos assim: a) ele preserva as preliminares, com a referência ao leito e outros adereços, à lâmpada, ao óleo, a abraços, palavras e carícias; b) preserva ainda o relativo à beleza da mulher, que excita o burro; c) mantém também a referência ao receio do animal de que pudesse matar a amante, tornando-se culpado de homicídio, sem detalhar que esse receio decorre do avantajado dos órgãos sexuais do asno, o que fica apenas subentendido; d) finalmente, resume todo o ato numa frase, conservando a referência a Pasífae:

Por fim, encorajado pelo exemplo de Pasífae, que amou sim um touro, assumi o dever de satisfazê-la e descobri que era muito sem razão que eu tinha esse receio (A la fin enhardy, par l'exemple de Pasifaé, qui avoit bien aimé un taureau, je me mis en devoir de la satisfaire, E trouvay que c'estoit à grand tort que j'avoit eu cette frayeur.).

Note-se que, na referência aos amores de Pasífae e Zeus sob a forma de touro, surpreendemos mais uma operação: éclaircir (esclarecer). De fato, para o leitor de Luciano era desnecessário explicar do que se tratava, o mesmo não se aplicando ao recebedor moderno - em geral, o tradutor, em casos semelhantes, resolve a dificuldade apelando para notas, como faz Magueijo, que esclarece no pé-de-página: "Pasífae, mulher de Minos, rei de Creta, apaixonou-se por um touro... donde nasceu o célebre Minotauro" (sem indicar que esse touro é Zeus numa de suas metamorfoses).

Tomemos uma última passagem forte de Lúcio ou o asno, a anedota final, quando o herói, após ter retomado a forma humana, se apresenta na casa da mulher que por ele se apaixonara quando era um burro, acreditando que, como homem, a agradaria mais, e decepciona-se ao descobrir que não era dele que ela gostava, mas dos atributos sexuais de burro, ou, nas palavras da mulher:

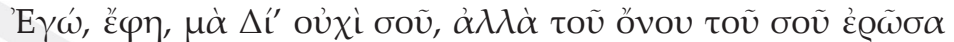

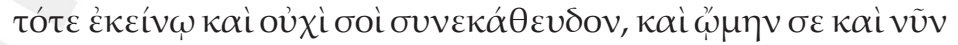

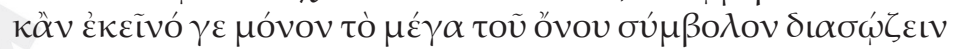

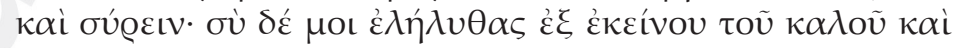

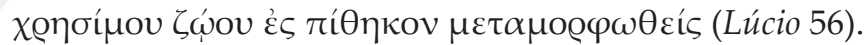

${ }^{40}$ Cf. anexo 2.2. 
É que, por Zeus!, o que eu amava não era a tua pessoa, mas sim o burro que tu eras; com esse, e não contigo, é que eu dormia; cuidava que tu ainda tivesses conservado e trouxesses contigo pelo menos aquele singular e enorme símbolo (sýmbolon) do burro, mas, em vez disso, apareces-me aqui feito macaco (Magueijo).

C'est parce que ie ne t'ay pas aimé, mes dist-elle, mais bien l'asne auec lequel i'ay couché. Ie croyois que tu n'eusses posé que la forme d'asne, te reseruant ce que i'auois chery de plus excellent en toy: Mais a ce que ie vois tu a perdu ce qui seul sembloit estre vtile à vn asne, $\mathcal{E}$ as esté transmué en ie ne sçay quel marmor (Baudoin).

Tanto em grego, quanto nas duas outras traduções citadas, só se entendem as referências cifradas aos órgãos do burro porque a reação da mulher se dá após Lúcio ter-se apresentado nu diante dela. D’Ablancourt modifica o entrecho eliminando essa cena de nudez, o que faz com que também a referência ao sexo do burro desapareça, ficando o interesse anterior da mulher debitado à conta de sua "curiosidade":

ela me disse muito bem-humorada que via bem que seu amor não tinha sido senão um efeito da curiosidade, porque ela não tinha mais a mesma paixão por mim, agora que eu era homem (elle me dit de fort bonne grace, qu'elle voyoit bien que son amour n'avoit esté qu'un effet de la curiosité, parce que'elle n'avoit plus la même passion pour moy, maintenant que j'estois homme).

Um traço observado na cena entre Lúcio e Palestra repete-se também aqui: a transferência do discurso da mulher, em primeira pessoa, para o narrador (elle me dit...). Por que proceder a essa mudança? Poderíamos entendê-la como um retoque (retoucher) que, ao mesmo tempo que corrige um pequeno defeito no original, o dispõe (agencie) à maneira elegante do século XVII? Noutros termos: do mesmo modo que pareceria impróprio pôr na boca de uma mulher as instruções (na verdade descrições) com que Palestra conduz o ato sexual, também o discurso da mulher anônima que rechaça Lúcio porque perdeu o que o burro tinha de melhor pareceria descabido, mesmo na forma mitigada que debita tudo a curiosidade (que apenas subentende-se que seja sexual).

Como se vê, Lúcio ou o asno levanta uma série de problemas para d'Ablancourt, relacionados com o que ele considerava marcas de saleté e, consequentemente, mostra de um espírito "debochado" em vez de "galante", a tal ponto que se poderia perguntar por que então tomou ele 
como desígnio traduzir essa história, se as condutas exigem, em certa medida, não apenas as intervenções usuais de salão, mas, se poderia dizer, em termos de hoje, verdadeiros procedimentos de cirurgia estética? Uma resposta poderia ser encontrada no argumento que antepõe ao texto um elemento importante, ainda que paratextual, pois, como vimos, é nele (e nas notas) que d'Ablancourt afirma que "responde ao que há de mais forte, a fim de que isso não possa causar prejuízo". No caso de Lúcio, logo após o título ele acrescenta: "O autor finge que, indo à Tessália, se alojou na casa de uma feiticeira, que se transformou em pássaro para ir encontrar um amante; mas, como se queria fazer o mesmo com ele, tomou-se uma caixa pela outra, e se o transformou em asno..." Prossegue-se com o resumo do enredo, acrescentando-se, no final, a observação de que "Apuleio se apossou desse tema, mas o estendeu mais longamente". "Há dois detalhes importantes que justificam o desígnio. O primeiro, que se trata de uma história famosa, tanto que Apuleio a retoma em latim, não incorrendo, diga-se, nas saletés de Luciano e provendo para sua narrativa mesmo um fecho piedoso, pois Lúcio volta à forma humana pela intervenção de Ísis, de quem era devoto (o fecho em Luciano são os impropérios da mulher que lamenta a perda do falo do burro). O segundo, a declaração inicial de que o "autor finge" tudo que narra em primeira pessoa, o que parece importante ressaltar, a fim de que o leitor se situe diante do texto, e, uma vez que tenha certeza de que se trata de fingimento, possa então fruir das railleries. ${ }^{42}$ São duas formas de "responder" não bem a Luciano, mas aos críticos que perguntariam por que traduzir tal escrito: porque é famoso, e quem o ler terá o benefício da instrução; porque é divertido e causará prazer a quem o lê. Finalmente, também de modo explícito em alguns casos, as notas garantem que o que era sale foi eliminado, bem como, implicitamente, saberá o leitor que o excessivamente livre foi adoçado, o

\footnotetext{
${ }^{41}$ Lucien, 1709, vol. II, p. 42 r.: L'Autheur feint qu'allant en Thessalie, il logea chez une Magicienne, qui se changea en oiseau pour aller trouver un Amant: mais comme on en vouloit faire autant de luy, on prit une boëte pour l'autre, E on le changea en Asne... (...) Apulée a derobé ce sujet, mais il l'a étendu plus au long.

${ }^{42} \mathrm{O}$ problema que o fato de a narrativa de Lúcio ou o asno levanta, por ser em primeira pessoa, já criava embaraço em Santo Agostinho, que conhecia a mesma história na versão de Apuleio, cf. Cidade de Deus XVIII, 18: Sicut Apuleius, in libris quo Asini aurei titulo inscripsit, sibi ipsi accidisse ut, accepto veneno, humano animo permanente, asinus fieret, aut indicavit aut finxit ("Assim Apuleio, no livro chamado Asno de ouro, escreveu a si próprio ter ocorrido que, tendo tomado uma poção, conservou a mente humana, tornando-se asno, como ou demonstra ou finge”.). Comentei o assunto em Brandão, 2005, p. 146-156.
} 
defeituoso, retocado - e tudo disposto em conformidade com o tempo, tornando Luciano, tachado de "debochado", simplesmente "galante".

Parece que, de fato, o mais grave que d'Ablancourt percebe em Luciano é o uso de imagens de sexo para provocar o riso - incluindo tudo relativo à homossexualidade. Assim, no fecho de $O$ sonho ou o galo, um diálogo de tendência cínica em que se faz o elogio da pobreza, mostrando-se como os ricos têm uma vida cheia de preocupações e misérias, a cena final mostra o abastado Êucrates, um homem já velho, "debaixo de seu criado" (hypò tôิ oikétou), entregue ao "desbunde" (katapygosýnen), a uma "paixão imoral" (paskhetiasmón) e uma "impudência” (asélgeian) indigna de um humano, enquanto, em outro local, também sua mulher se entrega ao cozinheiro, o que faz Mícilo, o sapateiro, concluir que prefere viver na pobreza, pois "dois óbolos são para mim riqueza maior que ser perfurado pelos criados”. D'Ablancourt muda bastante esse episódio: Êucrates, em vez de estar debaixo do criado, agora conta suas riquezas (o que, no original, era o que fazia outro rico, Simão); quem se entrega a atos sexuais, sem que Êucrates o saiba, são sua mulher, como em Luciano, e agora também sua filha - a primeira, como em Luciano, entregue ao cozinheiro; a segunda, em d'Ablancourt, a um "galante" (vois-tu sa femme couchée avec son cuisinier, Es sa fille d'un autre côté entre les bras d'un galant?).

Mudança também destinada a eliminar uma liberdade excessiva, agora sem referência a atos sexuais, mas simplesmente ao órgão masculino, encontramos em Narrativas verdadeiras: quase no final da viagem mirabolante que Luciano narra em primeira pessoa e em seu nome próprio, ele e seus companheiros encontram-se, no oceano, com os estranhos homens que são, a um só tempo, marinheiros e naus, pois, "deitados de costas sobre a água, tinham os pênis eretos (orthósantes tà aidoîa) — e os tinham grandes —, amarravam neles a vela, com as mãos controlavam a bolina e, quando o vento soprava, navegavam". ${ }^{43}$ A operação de d'Ablancourt, neste caso, foi mudar de "pênis ereto" para "um bastão entre as pernas, que servia de mastro" (c'étoient des gens couchés sur le dos avec un bâton entre les jambes, qui servoit comme de mât, où étoit attachée une petite voile qu'ils conduisoient avec la main, Ev voguoient ainsi sur l'océan) — descrição que Baudoin, por seu lado, abrandou mas deixou sem grandes alterações (auoient l'engin grand, droict, E tendu, auquel ils attachoient des voiles). ${ }^{44}$

\footnotetext{
${ }^{43}$ Narrativas verdadeiras 45 . Ver anexo 2.4.

${ }^{44} \mathrm{O}$ substantivo engin (instrumento, máquina) usa-se em sentido obsceno para designar tanto "le membre viril" (Trotterel:J'ai le plus bel engin qu'on saurait jamais voir) Qui travaille des mieux, qui fait bien son devoir.), quanto la nature de la femme (farces et moralités: "Et qu'elle avait l'engin trop ouvert/ Pour être faite religieuse.), cf. Landes, 1861.
} 
Em todos os exemplos que examinamos até agora, um traço de ordem geral é a maior brevidade das traduções de d'Ablancourt, o que confirma sua conduta declarada de, em quase toda parte, ser contido (resserré), sem descer a particularidades que não são mais deste tempo (e não posso me furtar a pensar que, também então, a primeira operação a que deve submeter-se a "bela" seria um regime de emagrecimento). Tomo agora como exemplo um texto que não ofereceria, em princípio, nenhuma dificuldade que pudesse ser debitada ao caráter debochado do autor: Como se deve escrever a história. As primeiras linhas da abertura já nos fornecem um bom exemplo, na simples confrontação de três traduções: a primeira minha, a segunda de Baudoin, a terceira de d'Ablancourt:

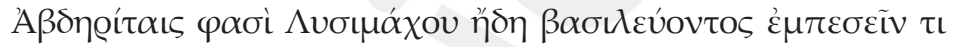

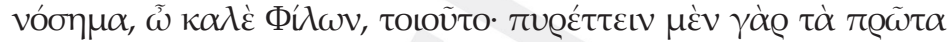

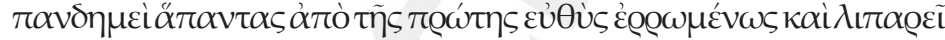

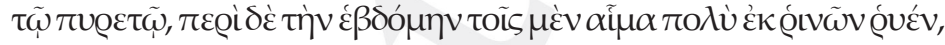

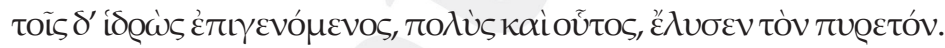

Sobre os habitantes de Abdera, na época em que Lisímaco reinava, dizem ter-se abatido uma certa doença, ó nobre Fílon, que era assim: no começo, todos, em massa, ficaram com febre, logo desde o primeiro dia violenta e persistentemente alta; no sétimo dia, alguns punham muito sangue pelo nariz e outros eram atacados por um suor abundante, ficando livres da febre (Brandão).

Ie ouy dire (cher Philon) que du temps du Roy Lisimachus il sunnint vne telle maladie entre les Abderites. Le peuple fut premierement trauaillé d'vne fiéure continuë; puis, d'vn flux de sang qui découlait parle nez, E n'abandonnoit iamais le patient jusqu'à ce qu'vne grande suëur le saissisant, elle chassoit le accez de fiéure (Baudoin).

On dit que sous le regne de Lysimachus, les habitants de la ville d'Abdere furent tourmentez d'une fievre chaude tres-violente, qui finissoit le septiéme jour par une perte de sang ou une suëur (D'Ablancourt).

Aplicado o regime, a "bela" conserva, no nível das informações (ou dos "pensamentos"), a referência ao rei Lisímaco, à febre alta e violenta e a seu fim no sétimo dia, eliminando-se a gordura do vocativo a Fílon e de dizer-se que a perda de sangue se dá pelo nariz. Registre-se que a retirada da referência ao destinatário constitui uma modificação que afeta a própria percepção do gênero do texto. 
Outro ponto importante do mesmo texto nos permitirá perceber melhor as operações da bela infiel. Trata-se da definição, da parte de Luciano, de como espera que seja o historiador, que cito no texto grego, em tradução minha (que procurou ser "escrupulosa", para servir de controle), e na de d'Ablancourt: ${ }^{45}$

\begin{tabular}{|c|c|c|}
\hline Luciano & Tradução escrupulosa & d'Ablancourt \\
\hline 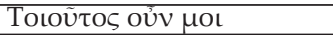 & Assim pois, para mim, & Je veus donc \\
\hline 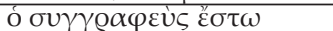 & o historiador seja: & que mon Historien \\
\hline$\alpha \ddot{\alpha} \varphi \mathrm{\beta} \beta \mathrm{\sigma} \varsigma$, & intimorato, & \multirow[b]{4}{*}{ aime dire la verité, } \\
\hline$\alpha \delta \varepsilon \kappa \alpha \sigma \tau \tau \zeta$, & incorruptível, & \\
\hline$\pi \alpha \varrho \emptyset \eta \dot{\alpha} \alpha \varsigma$ & da franqueza & \\
\hline 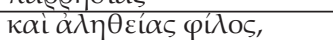 & e da verdade amigo, & \\
\hline 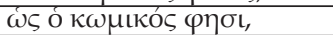 & como o cômico diz, & \multirow[b]{4}{*}{ \& n'ait point sujet de la taire. } \\
\hline$\tau \dot{\alpha} \sigma \tilde{v} \kappa \alpha \sigma \tilde{v} \kappa \alpha$ & os figos de figos, & \\
\hline$\tau \eta \dot{\nu} \sigma \kappa \alpha \dot{\alpha} \varphi \eta \nu \delta \dot{\varepsilon} \sigma \kappa \alpha \dot{\alpha} \varphi \nu$ & e a gamela de gamela & \\
\hline 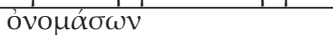 & chamando, & \\
\hline oú $\mu \dot{\sigma} \sigma \varepsilon \iota$ & não por ódio & \multirow{12}{*}{$\begin{array}{l}\text { Qu'il ne donne rien à la crainte, } \\
\text { ni à l'esperance, } \\
\text { ni à l'amitié, } \\
\text { ni à la haine; }\end{array}$} \\
\hline 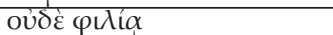 & nem por amizade & \\
\hline$\tau I \nu \varepsilon ́ \mu \omega \nu$ & algo admita & \\
\hline 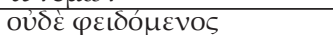 & nem omita, & \\
\hline$\hat{\eta} \varepsilon \lambda \varepsilon \tilde{\omega} v$ & seja poupando, & \\
\hline 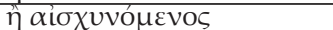 & seja respeitando, & \\
\hline$\eta$ & seja humilhando; & \\
\hline 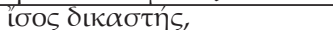 & juiz equânime, & \\
\hline$\varepsilon \ddot{v} v 0 u \varsigma \ddot{\alpha} \pi \alpha \sigma \mathrm{l} v$ & benevolente com todos & \\
\hline$\ddot{\alpha} \chi \varrho\llcorner\tau O \tilde{v} \mu \eta \dot{\eta} \theta \alpha \tau \dot{\varepsilon} \varrho \omega$ & até o ponto de não a um outro & \\
\hline$\tau \iota \dot{\alpha} \pi O \nu \varepsilon \tilde{\mu} \mu \alpha \iota$ & algo dar & \\
\hline 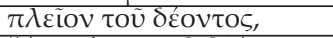 & mais que o devido; & \\
\hline 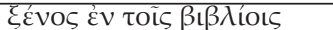 & estrangeiro nos livros & \multirow{4}{*}{ ne soit d'aucun pays, } \\
\hline$\kappa \alpha i \ddot{\alpha} \pi \mathrm{o} \lambda \mathrm{\iota} \varsigma$, & e sem-cidade, & \\
\hline$\alpha \hat{\tau} \tau o ́ v o \mu \sigma \varsigma$, & autônomo, & \\
\hline 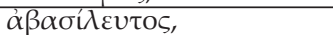 & sem-rei, & \\
\hline ou $\tau \dot{i} \tau \tilde{\omega} \delta \varepsilon \hat{\eta} \tau \tilde{\omega} \delta \varepsilon \delta \delta^{\prime} \xi \varepsilon \iota$ & $\begin{array}{l}\text { não o que a este ou àquele } \\
\text { parecera }\end{array}$ & \multirow{3}{*}{$\begin{array}{l}\text { \& apelle les choses par leur } \\
\text { nom, } \\
\text { sans se soucier ni d'offenser, } \\
\text { ni de plaire. }\end{array}$} \\
\hline 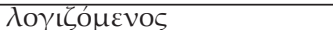 & calculando, & \\
\hline$\dot{\alpha} \lambda \hat{\lambda} \dot{\alpha} \tau \iota \pi \varepsilon \dot{\varepsilon} \pi \rho \alpha \kappa \tau \alpha \iota \lambda \dot{\varepsilon} \gamma \omega \nu$. & mas o que se fez dizendo. & \\
\hline
\end{tabular}

Considero que essa definição tem três movimentos: o primeiro, que afirma que o historiador deve ser intimorato, incorruptível, franco, verdadeiro e dar às coisas seu nome, imagem dominada pela do poeta cômico; o segundo, posto na esfera do juiz equânime que por nenhum motivo dá a alguém mais que o devido; finalmente, a terceira, sob o signo do estrangeiro nos livros, que, por sê-lo, é também apátrida, autônomo e sem-rei. Observese que o processo de contenção, que visa a efeitos estilísticos, preserva os três movimentos, eliminando, contudo, as imagens do poeta cômico, do juiz e do estrangeiro. ${ }^{46}$ No primeiro caso está em ação, provavelmente, a mudança motivada por livrar Luciano do excesso de citações e remissões a outros autores (aqui não se trata de aludir a Homero, mas, provavelmente,

\footnotetext{
${ }^{45}$ Como se deve escrever a história 41.

${ }^{46}$ Cf. meus comentários em Luciano, p. 258-269.
} 
a Aristófanes, nas Nuvens, ou a outro cômico desconhecido). Nos demais, o interesse em ser conciso. Observe-se que, na parte relativa ao estrangeiro (embora eu sempre lamente que os tradutores achem difícil e busquem paráfrases para expressar o belo sintagma "estrangeiro nos livros"), está em ação a operação que visa à modernização: em vez de "sem-rei" - e talvez também de "autônomo" (no sentido de quem tem suas próprias leis) —, d'Ablancourt verteu por não ser "de nenhum partido". ${ }^{47}$ O mais interessante, contudo, é que, no fecho da definição, d'Ablancourt retoma elementos que aparecem nas partes anteriores: a) "chame as coisas por seu nome" evidentemente retoma a ideia relacionada com o poeta cômico ("chame os figos de figos e a gamela de gamela"); b) "sem se preocupar nem em ofender nem em agradar", embora mantendo relações com "não se preocupando com o que achará este ou aquele", remete de algum modo para a parte do juiz. Não se pode dizer, portanto, que se perdeu algo em termos de conteúdo, ou seja, o but da definição foi preservado, o estilo é que foi transposto à la mode — uma moda que prefere (já então, pelo menos nas letras) as magras.

Tomemos um outro exemplo do mesmo texto, para verificarmos o que se faz com as constantes citações de Luciano, neste caso, citações de Homero. Trata-se de passagem importante, em que se provê a distinção entre a história, de um lado, e o encômio e a poesia, de outro. D'Ablancourt condensou-o assim (indico entre colchetes os locais em que cortou):

Premierement, quelle faute ne font point ces nouveaux Docteurs, lors qu'en lieu de raporter simplement les choses comme elles se sont passées, ils s'étendent dans le blâme ou la loüange des Chefs, \& font une Satyre ou un Panegyrique au lieu d'une Histoire; sans considerer que ces choses sont eloignées l'une de

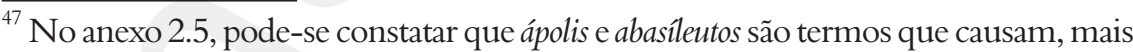
que dificuldade, constrangimento nos tradutores portugueses de Luciano do século XVIII. Frei Jacintho de São Miguel, que defende a tradução literal, é o único que opta simplesmente por "sem rei". Seu êmulo, o Frei Manoel de Santo António, adepto da tradução dos pensamentos, prefere "ninguém o mande". O caso do Pe. Custódio de Oliveira, patrocinado pelo Marquês de Pombal, é significativo: ele vale-se de uma perífrase para evitar dizer que o bom historiador deve ser "sem-rei", vertendo a palavra com "reconhecendo por único soberano a verdade". Já Baudoin a traduz por "sans se rendre esclaue d'autruy". Por esses exemplos, vê-se como se trata de uma declaração embaraçosa para várias épocas, provavelmente também para a de Luciano, que vive sob o poder de Roma e escreve seu tratado contra as histórias que engrandecem os feitos dos romanos na guerra contra os partos, recentemente terminada.
} 
l'autre, comme le ciel l'est de la terre. Car celui qui loüe n'a autre but que de réjoüir, E ne se soucie pas de le faire au préjudice de la verité; mais la moindre mensonge corrompt la nature de l'Histoire, E fait d'une verité une fable. L'Histoire ne s'accorde pas plus avec la Poësie, qui n'a pour bornes que la fantaisie du Poëte, dont la raison s'apelle fureur. [primeiro corte] Mais elle est plus chaste $\mathcal{E}$ ne peut employer les ornements de la Poësie, non plus qu'une honête femme ceux d'une Courtisane; [segundo corte] d'autant plus, qu'elle n'emprunte pas de secours des Fictions, E n'a pas les figures, E les mouvements qui transportent l'âme E la métent hors de son siege. Si vous y mélez donc trop d'ornements, vous la rendez semblable à Hercule vêtu des habits d'Onfale, qui est la derniere extravagance. ${ }^{48}$

Em primeiro lugar, que falta não cometem esses doutores novos, quando, em lugar de simplesmente contar as coisas como aconteceram, estendem-se na crítica e no elogio dos comandantes, e fazem uma sátira ou um panegírico no lugar da história, sem considerar que essas coisas estão longe uma da outra como o céu da terra. Pois aquele que louva não tem outro objetivo que alegrar e não se preocupa de fazê-lo em prejuízo da verdade; mas a menor mentira corrompe a natureza da história e faz de uma verdade uma fábula. A história não concorda mais com a poesia, que não tem como limites senão a fantasia do poeta, cuja razão se chama loucura. [primeiro corte] Mas ela é mais casta e não pode empregar os ornamentos da poesia, não mais que uma mulher honesta usaria os de uma cortesã; [segundo corte] mais ainda, que ela não tome emprestados os recursos da ficção, e não tenha as figuras e os movimentos que transportam a alma e a põem fora de si. Portanto, se vós misturais nela muitos ornamentos, fá-la-eis semelhante a Hércules vestido com as roupas de Ônfale, o que é a última das extravagâncias.

Deixando de lado outros aspectos já explorados nos exemplos anteriores — o que não significa que sejam menos interessantes, como a mudança da escala que indica a distância entre história e poesia de um diapasão para como a que há entre "o céu e a terra" — pretendo não mais que sublinhar os dois grandes cortes: o primeiro, das famosas remissões luciânicas a Homero (que seriam sentidas como pedantismo): cavalos voadores ou correndo sobre as águas e pontas de espigas, ${ }^{49} \mathrm{o}$ Zeus dos poetas que levanta ao mesmo tempo a terra e o mar, ${ }^{50}$ o louvor de Agamêmnon

\footnotetext{
${ }^{48}$ Lucien, 1709, p. 273-274. Para acompanhar os cortes no texto grego e em tradução minha, ver anexo 2.6.

${ }^{49}$ Ilíada XX, 226-229.
} 
que o compara a Zeus, Possêidon e Ares; ${ }^{51}$ o segundo, certamente para evitar as repetições do texto de Luciano, o que apenas reforça as ideias já expostas, mas também para eliminar a referência ao amor des garçons presente na história dos atletas Nicóstrato e o belo Alceu de Mileto.

Finalmente, para testar a última declaração programática relativa às condutas de d'Ablancourt, cumpre buscar algum exemplo de trecho traduzido mot à mot. Isso será importante como testemunho do encontro entre os dois estilos — o de Luciano e o de seu tradutor —, o que pode servir como a justificativa mais eloquente da admiração deste por aquele, a qual se encontra na origem do desígnio que pôs em marcha o esforço tradutório. Escolho como exemplo a anedota atribuída a Platão, que se encontra no Hermótimo, um diálogo dedicado à crítica da filosofia e dos filósofos, valendo recordar que esse é um dos traços de Luciano que fazem com que deva ser traduzido: por ele mostrar "o orgulho e ignorância dos filósofos":

\begin{tabular}{|c|c|c|}
\hline Luciano & Tradução escrupulosa & D'Ablancourt \\
\hline 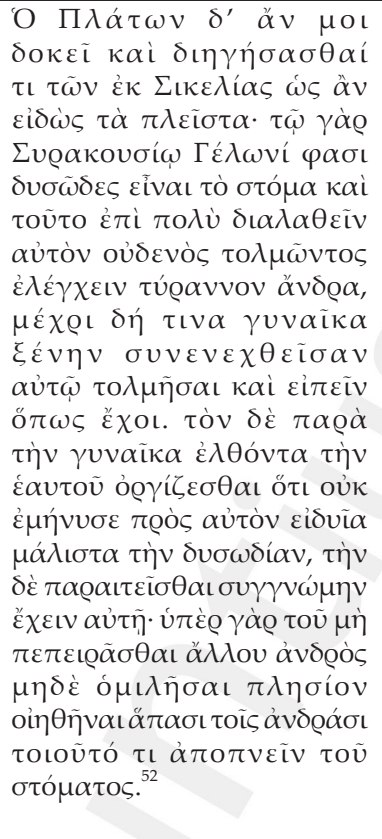 & $\begin{array}{l}\text { Platão, parece-me, também } \\
\text { contaria uma das suas sobre } \\
\text { a Sicília, ele que conhecia } \\
\text { muitas: diz-se que a boca de } \\
\text { Gelão de Siracusa cheirava } \\
\text { mal, mas isso foi escondido } \\
\text { dele durante muito tempo, } \\
\text { pois ninguém ousava } \\
\text { advertir um tirano, até uma } \\
\text { certa mulher estrangeira, } \\
\text { tendo dormido com ele, ser } \\
\text { ousada e dizer-lhe o que se } \\
\text { passava. Voltando ele para } \\
\text { junto de sua própria mulher, } \\
\text { encolerizou-se por ela não } \\
\text { tê-lo advertido, conhecendo } \\
\text { mais que ninguém o mau } \\
\text { cheiro. Ela suplicou-lhe que } \\
\text { a perdoasse, pois, não tendo } \\
\text { nunca tido experiência com } \\
\text { nenhum outro homem, } \\
\text { nem ao menos tratado de } \\
\text { perto com algum, cria que } \\
\text { o mesmo cheiro exalava da } \\
\text { boca de todos os homens. }\end{array}$ & $\begin{array}{l}\text {...mais Platon, qui a esté } \\
\text { en Sicile, y ajoutera peut- } \\
\text { estre l'exemple de Gélon de } \\
\text { Syracuse, qui fut long-tems } \\
\text { sans sçavoir qu'il avoit l'haleine } \\
\text { mauvaise, jusqu'à ce qu'une } \\
\text { Courtisane le luy aprit. Alors, } \\
\text { il ala tout en colere trouver sa } \\
\text { femme, \& luy dit des injures } \\
\text { de ce qu'elle luy avoit celé si } \\
\text { long-tems un defaut, où il eût } \\
\text { pu aporter quelque remede. } \\
\text { Mais elle s'excusa sur ce qu'elle } \\
\text { croyoit tous les hommes faits } \\
\text { de la sorte, n'ayant jamais } \\
\text { pratiqué que son mary. }\end{array}$ \\
\hline
\end{tabular}

${ }^{50}$ Ilíada VIII, 248.

${ }^{51}$ Ilíada II, 478-479.

${ }^{52}$ Hermótimo 34.

${ }^{53}$ Lucien, 1709, vol. II, p. 248. 
Ainda que a regra geral da concisão persista, a cosmética foi bastante delicada: a) eliminou-se a alusão a que Platão sabia muitas histórias de Siracusa; b) substitui-se o nome desta cidade pelo da ilha, a Sicília; c) esclareceu-se que Platão estivera lá; d) eliminou-se a informação de que Gelão dormira com a mulher, o que todavia se subentende do fato de ela ser tratada de "cortesã"; e) suprimiu-se a informação de que a mulher era uma estrangeira, o que parece consequência do fato de que se cortou a consideração de que Gelão desconhecia o mau cheiro por ninguém ousar advertir um tirano; f) acrescentou-se que Gelão proferiu "injúrias” contra a própria mulher por ela ter-lhe escondido o fato; g) acrescentou-se mais um esclarecimento, o de que, se ela o tivesse alertado, ele poderia ter buscado um "remédio"; h) reduziram-se as duas informações finais — ter experimentado ou ao menos ter tratado de perto com algum outro homem - a uma só: não ter jamais falado senão com seu marido.

Ora, embora essa anedota - que eu considero uma das melhores de Luciano - tenha elementos grotescos (o mau hálito e a prostituta estrangeira), a forma como d'Ablancourt a trata, sem cortes, mostra que, neste caso, ele considera que Luciano se mostrou galante e não debochado. Poderíamos dizer que se trata de uma piada de "salão", que pode ser conservada na íntegra e traduzida palavra por palavra, apenas com os pequenos ajustes devidos à elegância. Um bom exemplo que serve para alertar-nos de que a tradução mot à mot, da perspectiva de d'Ablancourt, jamais se confundirá com as "traduções escrupulosas", que não são propriamente tradução, mas idolatria. Finalmente, cumpre insistir que ele declara que, quase por toda a parte, traduziu assim: ou seja, essa seria sua forma de trabalho rotineira, enquanto operações mais radicais se aplicariam somente em passagens que oferecessem dificuldades de maior monta.

\section{As práticas do salão (2): traduzir o intraduzível}

Vimos como d'Ablancourt afirmou que houve alguns três ou quatro textos que não se pôde traduzir, nomeadamente o Julgamento das vogais. Trata-se de uma peça curiosa, inspirada nos progymnásmata usuais nas escolas de retórica, em que Luciano cria um tribunal, em que são juízes as sete vogais gregas, às quais compete julgar a ação que o Sigma moveu contra o Tau, acusando-o de roubar-lhe um sem número de palavras. O que se encontra na motivação da peça é uma questão de variação linguística, já que, em palavras em que o grego comum apresenta dois sigmas, como thálassa, o ático costuma usar dois taus, thálatta. Portanto, o que Luciano explora são as diferenças sempre cômicas entre falares. 
D'Ablancourt considerou o texto intraduzível em vista de tratar-se de "uma peça plena de jogos de espírito, cujo achado consiste apenas nas palavras", o que fez com que fosse "impossível dar-lhe um sentido em francês preservando o do autor". ${ }^{54} \mathrm{O}$ que não torna, portanto, possível traduzi-lo é que fazê-lo implicaria desrespeitar o objetivo (but) de Luciano - e a preservação deste é a regra máxima do cânon de d'Ablancourt, da qual deriva todo seu receituário de condutas. Assim, configura-se um dos problemas mais graves dentre todos. O que fazer? A solução foi encaminhada em dupla direção: a) não dar o texto no corpus luciânico; b) mas acrescentar, em apêndice, no final do volume, um Diálogo das Letras do Alfabeto, em que o Uso e a Gramática falam, assinado por "Monsieur de Fremont, sobrinho do tradutor", ${ }^{55}$ que aproveita a "invenção" de Luciano, com a seguinte explicação:

Se o Julgamento das Vogais tivesse podido ser dado em nossa língua, com toda sua simplicidade \& sua graça, não se teria empreendido esta obra. Mas, como é uma peça plena de jogos de espírito, cujo achado consiste apenas nas palavras, foi impossível dar-lhe um sentido em francês, preservando o do autor. Tudo o que se pôde fazer foi aproveitar de sua invenção e, para ter mais matéria para divertir, fez-se com que falassem todas as letras do Alfabeto, uma após a outra, diante do Uso e da Gramática, dos quais um atua como o Juiz e a outra como o Advogado Geral. De resto, essa galanteria não é inútil: pois pode-se aprender com ela muitas coisas curiosíssimas a respeito da ortografia e da pronúncia. ${ }^{56}$

\footnotetext{
${ }^{54}$ Lucien, 1709, vol. II, p. 393. Esta não foi a postura de Baudoin, que traduziu o texto, começando assim: La Ivstice des voyelles/ Regnant le Grammarien Aristarque Phalerien, le septiesme iour du mois d'Octobre la lettre $S$, intenta procez à l'encontre de T, pardevant mes Dames les Voyelles seantes en leur siege, pour vn faict de rapt, $\mathcal{E}$ de larrecin, se disant estre frustree de tous les mots qui sont prononcez par le double T./ Vous devez savoir (mes Dames les Voyelles) que pendant tout ce temps que i'ay reçeu des affronts par le T... (Lucian, 1613, p. 131).

${ }^{55}$ Nicolas Fremont d'Ablancourt, sobrinho de Nicolas Perrot d'Ablancourt, nasceu em Paris em 1625 e faleceu, em La Haye, por volta de 1692. Escreveu suas Memórias, abordando acontecimentos políticos a partir de 1659, livro publicado em Amsterdam, em 1701.

${ }^{56}$ Lucien, 1709, vol. II, p. 393: Si «Le Jugement des Voyelles» avoit pû se rendre en nôtre langue, avec toutes ses naivetés \& ses graces, on n'auroit pas entrepris cet Ouvrage; Mais comme c'est une piece pleine de jeux d'esprit, dont la rencontre ne consiste que dans les mots, il a esté impossible de luy donner un sens en François en gardant celuy de l'Auteur. Tout ce qu'on a pû faire, ç'a esté de profiter de son invention, E pour avoir plus de matiere de s'egayer, on a fait parler toutes les lettres de l'Alphabet l'une après l'autre, devant l'Usage E la Grammaire, dont l'un est comme le Juge, et l'autre comme l'Avocat General. Du reste, cette galanterie n'est pas inutile: car on y peut aprendre plusieurs choses tres-curieuses, touchant l'ortographie E la prononciation.
} 
De fato, neste caso já se trata do que não é mais tradução, mas melhor que a tradução: escrever no espírito de Luciano, continuar sua "invenção", expandir seu corpus.

Outro exemplo é ainda mais curioso. Narrativas verdadeiras termina com uma declaração intrigante do narrador: "Estas são as coisas que me aconteceram até a chegada na outra terra (...). O acontecido em terra

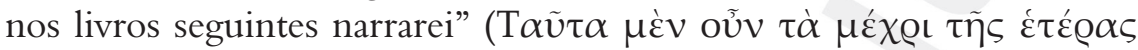

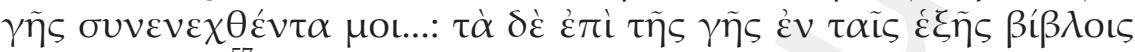

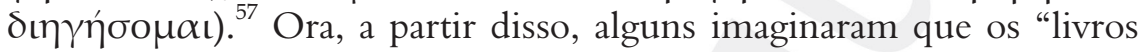
seguintes" se tivessem perdido, como tantos outros da Antiguidade muito embora um escoliasta bizantino já tivesse anotado, à margem do texto, que essa seria a maior das mentiras de Luciano, como era de esperarse numa história que o próprio autor abrira com a declaração de que tudo que diria não passaria de mentira. ${ }^{58}$

D’Ablancourt, considerando que a promessa dos livros seguintes não se cumpriu, ou por eles se terem perdido ou por outra razão, termina sua tradução assim: "Eis o que me aconteceu em minha viagem do novo Mundo; descreverei nos livros seguintes as maravilhas que vi lá" — e acrescenta: "O suplemento desta história encontra-se no fim do segundo volume". Nesse local, com o título de "Suplemento da História verdadeira", dá-se a seguinte explicação:

Lucien ayant dit à la fin du Second Livre de cette Histoire, qu'il aloit décrire en-suite les merveilles qu'il avoit veïes aux Antipodes, E cela ne se trouvant point, soit que les Livres ayent esté perdus, ou autrement, il a pris envie a celuy qui a fait le precedent Dialogue de se joüer à son exemple, en des aventures étranges E inoüies, Mais comme il n'y a rien de si facile, que de feindre des choses qui n'ayent aucun fondement dans la Raison ni dans la Nature, il n'a pas cru le devoir imiter en ce point; E n'a rien dit, qui n'ait quelque sens allegorique, ou quelque instruction mélée avec le plaisir.

\footnotetext{
${ }^{57}$ Narrativas verdadeiras 47.

${ }^{58}$ Narrativas verdadeiras 1: Já que não tinha nada de verídico para narrar (...), virei-me para a mentira, mas uma mentira mais desculpável que a daqueles, porquanto numa coisa serei verdadeiro: ao confessar que minto. (...) Escrevo, pois, sobre coisas que não testemunhei nem experimentei, e que não soube da boca doutrem; mais ainda: que não existem em absoluto e que, de qualquer forma, não são susceptíveis de ocorrer. Portanto, não deve o leitor dar o mínimo crédito às minhas histórias (tradução de Magueijo, p. 19).
} 
Tendo dito Luciano, no fim do segundo livro desta história, que iria descrever em seguida as maravilhas que viu nos antípodas, e isso não se encontrando absolutamente, seja que os livros se perderam, ou de outro modo, o desejo tomou àquele que fez o diálogo precedente de brincar, à exemplo dele, em aventuras estranhas e inauditas. Mas como não há nada mais fácil que fingir coisas que não têm nenhum fundamento na Razão nem na Natureza, ele não creu que deveria imitá-lo nesse ponto, e não disse nada que não tivesse algum sentido alegórico ou alguma instrução misturada com o prazer. ${ }^{59}$

Desse modo, trata-se de nova expansão do corpus luciânico, nos termos de d'Ablancourt, mais um “suplemento", que se justifica por várias razões, a primeira delas a forma como foi traduzida a declaração final de Luciano: tendo este dito que "essas coisas [lh] e aconteceram até (mékhri) a chegada na outra terra" - a que se acrescenta o resumo das aventuras marítimas e aéreas até então experimentadas, promete ele que "o acontecido em terra narrar[á] nos livros seguintes"; ora, d'Ablancourt procedeu a uma mudança discreta, mas importante, ao verter a declaração luciânica por "eis o que me aconteceu em minha viagem do novo Mundo; descreverei nos livros seguintes as maravilhas que vi lá", transportando o que "aconteceu" apenas do já dito para o todo o conjunto - como se os dois primeiros livros e os dois que se lhe acresceram formassem uma unidade bem articulada e, afinal, fizessem parte das inúmeras aventuras pelo Novo Mundo, em que agora se transforma a "outra terra" de Luciano.

Convém ressaltar que, como no caso precedente do Julgamento das vogais, preside a essa operação um interesse educativo — ou seja, uma função nobre que se empresta à bela infiel, que, pelo menos nestes casos, justifica sua infidelidade pelo interesse pedagógico. Mais ainda: esse procedimento acrescenta também a Luciano um "sentido alegórico", que se admite que ele não teve nos dois livros que escreveu de fato, motivo por que não deve ser imitado quanto a isso. Finalmente, eu diria que há também um imperativo estético que preside à necessidade de continuação: como se conta com dois livros de Luciano sobre as aventuras no mar, era mister escrever, fosse qual fosse o motivo da ausência, outros dois sobre o acontecido na "outra terra".

Não tenho como analisar essa continuação, que leva os aventureiros à terra dos animais e dos contos, mas desejo destacar apenas como procura

\footnotetext{
${ }^{59}$ Lucien, 1709, vol. II, p. 414. O “diálogo precedente” é o Julgamento das vogais, logo, o texto se atribui também a M. de Fremont. Não tenho conhecimento se ambas as atribuições são autênticas ou se se trata de burla do próprio d'Ablancourt.
} 
dar-se à história um fecho apaziguador: "E nos encontramos cada qual, uma manhã, em nosso leito, como se toda a viagem que fizemos não tivesse sido senão um longo sonho" ( $\mathcal{E}$ nous nous trouvâmes chacun un matin dans notre lit, comme si tout le voyage que nous avions fait, n'avoit été qu'un long songe). Esse "como se", de fato, põe todo o texto, inclusive os dois primeiros livros, num registro novo: tudo pode não ter passado de sonho. Recorde-se que, conforme o próprio Luciano, os poetas, os pintores e os sonhos não têm de prestar contas a ninguém com relação ao que plasmam, pois são livres - o que garante que a solução de d'Ablancourt no fundo conserva o caráter luciânico.

\section{Tradução, imitação e emulação}

Conforme Kelly, uma teoria completa da tradução deve ter "três componentes: a especificação da função e dos objetivos; a descrição e análise das operações; e comentários críticos da relação entre objetivos e operações". ${ }^{60}$ Pode-se dizer que, no caso do "Luciano de Ablancourt", esse requisito se realiza, levando-se em conta o que se afirma na cartadedicatória, nos argumentos e notas, bem como o modo como se aplicam os princípios na própria tradução.

Afirmei no início que o gosto estético contemporâneo nos permite apreciar melhor o trabalho de d'Ablancourt que no século XIX e em boa parte do XX. Isso se dá, todavia, a partir de uma perspectiva que se abre para a compreensão de que há várias formas de traduzir e que a tradução é uma tarefa ininterrupta: conforme Sorel, é necessário atualizar as traduções a cada vinte anos, o que se aplica especialmente aos clássicos. ${ }^{61}$ Mas, a partir das operações apontadas, o trabalho de d'Ablancourt ainda seria legível hoje? Sem dúvida a resposta deve ser positiva, caso se o leia como "original", situação em que prevaleceriam as qualidades de língua e estilo. Em certa medida, também seus preceitos poderiam ser atuais, ainda que, para o público contemporâneo que se vale de traduções, saber que se procedeu a mudanças num texto possa ser um alerta que tenha sentido negativo - talvez por uma perspectiva ingênua de que é possível haver traduções "escrupulosas", o que se aplicaria em maior grau a textos como os sagrados e os clássicos que se sacralizam, talvez pela expectativa criada pelas traduções que Bury chama de "filológicas",

\footnotetext{
${ }^{60}$ Apud Venuti, 2004, p. 5.

${ }^{61}$ Sorel, C. La bibliothèque françoise. Paris: 1664, p. 240. Apud Bury, Trois traducteurs français aux XVIe et XVIIe siècles, p. 367.
} 
pela ideia de "originalidade" e de propriedade intelectual, o que, apesar do "não há nada de novo", ainda ronda nossa concepção de literatura. É bem verdade que, para ser plenamente legível, o "Luciano de Ablancourt" deveria sofrer novas operações que lhe restituíssem os cortes mais radicais, transformando-os, assim, em mais um motivo de interesse para o leitor.

Numa das raras cartas conservadas da correspondência de d'Ablancourt, ele afirma, dirigindo-se a M. de Saumaise, a quem envia sua tradução de Tácito, que "esse livro não merece ser lido por alguém que possui, como vós, o seu Tácito”, por ser não mais que "uma tradução que fui obrigado a fazer a pedido de alguns amigos", a qual — ele continua "creio que poderá contentar aqueles que tenham ouvido falar do original e não o poderiam ler em sua língua". ${ }^{2}$ Trata-se, neste caso, do dilema entre tradução e original, que talvez não se resolva de modo tão simples. E como está em causa um autor antigo, a discussão deve ser situada na esfera da tradição literária e não de toda e qualquer tradução.

Como as modas mudam com os tempos, d'Ablancourt, pode-se dizer, já no século seguinte caiu em relativo esquecimento — mais suas "belas" que propriamente suas ideias a respeito da infidelidade. Mas, talvez pela consagração por ele recebida ao ingressar na Academia Francesa exclusivamente em vista de seu trabalho como tradutor, a impressão que se tinha, quando de sua morte, era de que sua obra continuaria a agradar também as gerações futuras, tanto quanto agradara os contemporâneos (e os próprios antigos!), a crer-se nos termos do epitáfio que lhe compôs o já citado Gédéon Tallemant des Réaux:

L'illustre d'Ablancourt repose en ce tombeau,

\footnotetext{
${ }^{62}$ D'Ablancourt, 1858, p. 243-245: Monsieur, Je n'aurois pas attendu si longtemps à vous donner le livre que $M$. Ménage vous présentera de ma part, sans le bruit qui couroit que vous seriez en France dès le printemps; vous n'avez rien perdu à l'attente, car le livre ne mérite pas d'estre lu par une personne qui possède comme vous son Tacite. C'est une traduction que j'ay esté obligé de faire à la prière de quelques amis, et comme je crois qu'elle pourra contenter ceux qui auroient ouï parler de l'original, et qui ne le pouroient avoir en sa langue, je n'ay pas aussy la vanité de croire qu'une personne d'une doctrine si éminente que M. de Saumaise y puisse rencontrer sa satisfaction. Recevez-le donc simplement comme un tesmoignage de mon affection, et non pas de l'estime que je fais de mon ouvrage, et vous imputer à vous-mesme l'ennui que vous pourra causer la lecture, puisque je n'aurois pas eu la hardiesse de vous l'envoyer, si vous n'aviez pas marqué de mescontentement de ce que je ne vous avois pas envoyé les autres. Votre très-humble et très-passionné serviteur, Perrot d'Abl. Chaalon, 5 de novembre (1659?).
} 
Son génie à son siècle a servi de flambeau.

Dans ses fameux écrits toute la France admire

Des Grecs et des Romains les précieux tresors.

À son trespas on ne peut dire

Qui perdit plus, des vivants ou des morts,

epitáfio que me arrisco a traduzir assim:

O nobre d'Ablancourt repousa em seu túmulo,

Seu gênio, em seu século, atingiu o cúmulo.

Em seus escritos a França sempre verá

Dos gregos e romanos tesouros e votos.

Com sua morte, quem dirá

Quem perde mais: os vivos ou os mortos.

\section{Referências}

BOMPAIRE, J. Introduction. In: LUCIEN. Oeuvres. Paris: Les Belles Lettres, 1993, p. XI-CLXIV.

BRANDÃO, J. L. A invenção do romance. Brasília: Editora UnB, 2005.

BRANDÃO, J. L. Las bellas infieles: Luciano en el salón de M. d'Ablancourt. Argos, Buenos Aires, vol. 33, p. 7-24, 2010.

BURY, E. Trois traducteurs français aux XVIe et XVIIe siècles: Amyot, Baudoin, D'Ablancourt. Revue d'histoire littéraire de la France, Paris, vol. 97, n. 3, p. 361-371, 1997.

CASA NOVA, V. O novo é uma ilusão, afirma coordenadora da área de literatura do Festival. Entrevista concedida no dia 22 de julho de 2009, < http://www.ufmg. br/online/arquivos/012522.shtml >.

D'ABLANCOURT, N. P. À M. de Saumaise. Le cabinet historique: t. 4, $1^{a}$. parte, Paris, p. 243-245, 1858.

de FAVERI, C. B.; TORRES, M.-H. C. (org.). Clássicos da teoria da tradução: antologia bilíngue. Florianópolis: Universidade Federal de Santa Catarina, 2004.

de LANDES, L. Glossaire érotique de la langue française depuis son origine jusqu'à nos jours, contenant l'explication de tous les mots consacrés à l'amour. Bruxelas: Ch. Vanderauwera, 1861.

LONGUERUE, A. D'Ablancourt. Le cabinet historique: revue mensuelle, Paris, t. 4, 1e. partie, p. 243-245, 1858.

LUCIAN DE SAMOSATE. Les oeuvres de Lucian de Samosate Autheur Grec. De nouueau traduites en François \& illustrées d'Annotations \& de Maximes Politiques en Marge p. I. B. A Paris: Chez Iean Richer, [1613].

LUCIANO. Arte histórica de Luciano Samossateno, Traduzida do grego em duas 
versões portuguezas pelos Revs. Padres Fr. Jacintho de São Miguel, cronista da congregação de S. Jeronymo, e Fr. Manoel de Santo António, monge da mesma congregação em Portugal. Dadas à luz pelo Padre Joseph Henriques de Figueiredo, presbytero do habito de S. Pedro e capellão da Rainha Nossa Senhora. Lisboa Occidental: Officina da Musica, 1733.

LUCIANO. Sobre o modo de escrever a História. Trad. Custódio José de Oliveira. Lisboa: Régia Oficina Tipográfica, 1771, p. 84.

LUCIANO DE SAMÓSATA. Como se deve escrever a história. Trad. Jacyntho Lins Brandão. Belo Horizonte: Tessitura, 2009.

LUCIANO DE SAMÓSATA. Eu, Lúcio: memórias de um burro. Prefácio, tradução e notas de Custódio Magueijo. Lisboa: Inquérito, 1992.

LUCIANO DE SAMÓSATA. Histórias verdadeiras. Trad. de Théo de Borba Moosburger. Porto Alegre: Plus, 2009.

LUCIANO DE SAMÓSATA. Uma história verídica. Trad. Custódio Magueijo. Lisboa: Inquérito, s.d.

LUCIEN. Histoire véritable de Lucien. Traduite \& continuée par Perrot d'Ablancourt. Reproduction partielle du tome XIII des Voyages imaginaires (Amsterdam 1787). Nancy: Presses Universitaires de Nancy, 1984, p. 53 (edição facsímile).

LUCIEN. Lucien de la traduction de N. Perrot, Sr. d'Ablancourt. Divisé em deux parties. Nouvelle edition, revüe \& corrigée. Amsterdam: Pierre Mortier, 1709.

de SÃO MIGUEL, J. Ao Excelentíssimo Senhor D. Francisco Xavier Joseph de Menezes, Conde de Ericeira. In: LUCIANO. Arte histórica de Luciano Samossateno. Lisboa: Officina da Musica, 1733.

SELIGMANN-SILVA, M. Do gênio da língua ao tradutor como gênio. In: MARQUES, Luiz. A constituição da tradução clássica. São Paulo: Hedra, 2004.

TALLEMANT, P. D’Ablancourt. Le cabinet historique: revue mensuelle, Paris, t. 4, 1e partie, p. 243-245, 1858.

VENUTI, L. The translations studies reader. London/ New York: Rouledge, 2004.

ZUBER, R. Les Belles Infidèles et la formation du goût classique. Paris: A. Colin, 1995. 


\section{Anexo 1 \\ Extrato da carta-dedicatória a M. Conrart ${ }^{63}$}

[p. 3 r.]

A Monsieur

Conrart

\section{Conseiller \& Secretaire du Roy}

Comme les choses retournent à leur principe, \& finissent ordinairement par où elles ont commencé, il estoit juste de consacrer la fin de mes Traductions, à celuy qui en avoit eu les prémices; \& Minuncius Felix ayant donné naissance à nôtre amitié, Lucien en devoit faire comme l'accomplissement. D'ailleurs, il faloit métre au frontispice de cet Ouvrage, un nom qui banît toute la mauvaise opinion, que l'on pourroit avoir; \& que le libertinage de cét Auteur fût effacé par la vertu de Monsieur Conrart. Ajoûtez à cela, que ce Livre ne pouvoit honêtement paroître em public sous d'autres auspices, que de celuy, de qui les soins ont tant contribué à sa production. (...) [p. 3 v.] Et veritablement, Monsieur, puisque c'est vous principalement qui m'avez fait entreprendre cette Version, vous devez avoir part au blâme ou à la loüange qui en pourra revenir: outre qu'elle trouvera assez de monstres à combatre à sa naissance, pour chercher un Protecteur. (...)

Tout ce qu'on peut dire contre moy, se peut raporter à deux Chefs, au Dessein \& à la Conduite. Car les uns diront qu'il ne faloit pas traduire cet Auteur: les autres, qu'il le faloit traduire autrement. Je veus donc répondre à ces deux objections, aprés avoir [p. 4 r.] dit quelque chose de Lucien, qui servira à ma justification, \& fera mieux voir les raisons que j'ay eües de le traduire. [p. 5 v.] Mais on ne peut nier que ce ne soit un des plus beaux Esprits de son siecle, qui a par tout de la mignardise \& de l'agréement, avec une humeur gaye \& enjouée, \& cette urbanité Attique, que nous apellerions en nôtre langue une raillerie fine $\&$ delicate, sans parler de la néteté $\&$ de la pureté de son stile, jointes à son élegance $\&$ sa politesse. Je

\footnotetext{
${ }^{63}$ Reproduzo apenas os trechos que dizem respeito às questões relativas à tradução: no que se refere aos desígnios, deixei de lado as informações relativas à vida de Luciano e considerações de ordem geral sobre sua obra; o que se refere à conduta encontra-se integralmente reproduzido. Respeitei a ortografia e a pontuação da edição de 1709.
} 
le trouve seulement un peut grossier, dans les choses de l'Amour, soit que cela se doive imputer au genie de son tems, ou au sien: mais lorqu'il en veut parler, il sort des bornes de l'honêteté, \& tombe incontinent dans le sale: ce qui est plutôt la marque d'un esprit débauché que galant. (...) Mais c'est une grande preuve du merite $\&$ de l'excellence de ses Ouvrages, qu'ils se soient conservez jusqu'à nous, veu le peu d'affection qu'on avoit pour leur Auteur, \& le naufrage de tant d'autres pieces de l'Antiquité, qui se sont per-[p. 6 r.]-dues. (...) Aussi jamais homme n'a mieux découvert la vanité \& l'imposture des faux Dieux, ni l'orgueil \& l'ignorance des Filosofes, avec la foiblesse $\&$ l'inconstance des choses humaines: $\&$ je doute qu'il y ait de meilleurs Livres pour ce regard. Car il s'insinüe doucement dans les esprits par la raillerie: \& sa Morale est d'autant plus utile, qu'elle est agréable. D'ailleurs, on peu aprendre icy mile choses tres-curieuses, \& c'est comme un bouquet de fleurs de ce qu'il y a de plus beau chez les Anciens. Je laisse à part, que les Fables sont traitées d'une façon ingenieuse, qui est tres-propre à les faire retenir, \& ne contribüe pas peu à l'intelligence des Poëtes. Il ne faut donc pas trouver étrange que je l'aye traduit, à l'exemple de plussieurs Personnes doctes, qui ont fait des Versions Latines, les uns d'un Dialogue, les autres d'un autre: \& je suis d'autant moins blâmable, que [6 v.] j'ay retranché ce qu'il y avoit de plus sale, \& adoucy en quelques endroits, ce qui estoit trop libre, par où j'entre en la justification de ma conduite, puisque voilà mon dessein assez bien justifié par tant d'avantages qui peuvent revenir au public, de la lecture de cet Auteur. Je diray seulement que je luy ay laissé ses opinions toutes entieres, parce qu'autrement ce ne seroit pas une Traduction; mais je répons dans l'Argument ou dans les Remarques, à ce qu'il y a de plus fort, afin que cela ne puisse nuire.

Comme la plûpart des choses qui sont icy, ne sont que de gentilesses $\&$ des railleries, qui sont diverses dans toutes les Langues, on n'en pouvoit faire de Traduction reguliere. Il y a même Pieces qui n'on pû se traduire $\mathrm{du}$ tout, comme celle du Jugement des voyelles, \& deux ou trois autres semblables, qui consistent dans la proprieté des termes Grecs, \& qui ne seroient pas entendües hors de là. Toutes les comparaisons tirées de l'Amour y parlent de celuy des Garçons, qui n'estoit [p. 7 r.] pas étrange aux moeurs de la Grece, \& feroit horreur aux nôtres. l'Auteur allegue à tout propos des vers d'Homere, qui seroient maintenant des pedanteries, sans parler des vieilles Fables trop rebatües, de Proverbes, d'Exemples \& de Comparaisons surannées, qui feroient à present un effet tout contraire à son dessein: car il s'agit icy de galanterie, \& non pas d'erudition. Il a donc falu changer tout cela, pour faire quelque chose d'agréable: autrement ce ne seroit Lucien: \& ce qui plaît en sa langue, ne seroit pas suportable en la nôtre. D'ailleurs, comme dans les beaux visages il y a toûjours quelque 
chose qu'on voudroit qui n'y fût pas: aussi dans les meilleurs Auteurs il y a des endroits qu'il faut retoucher ou éclaircir, particulierement quand les choses ne sont faites que pour le plaisir: car alors on ne peut soûfrir le moindre defaut: \& pour peu qu'on manque de delicatesse, au lieu de divertir on ennuye. Je ne m'attache donc pas toujours au paroles ni aux pensées de cét Auteur: \& demeurant dans son [p. 7 v.] but, j'agence les choses à nôtre air \& à nôtre façon. Les divers tems veulent non-seulement des paroles, mais de pensées differentes, \& les Ambassadeurs ont coûtume de s'habiller à la mode du päys où on les envoye, de peur d'estre ridicules à ceux à qui ils tâchent de plaire. Cependant, cet n'est pas proprement de la Traduction, mais cela vaut mieux que la Traduction, \& les Anciens na traduisoient point autrement. C'est ainsi que Terencer en a usé dans les Comedies qu'il a prises de Menandre, quoy qu'Aulugelle ne laisse pas de les nommer des Traductions ${ }^{64}$, mais il n'importe du nom, pourvu que nous ayons la chose. Ciceron a fait autant dans ses Offices, qui ne sont presque qu'une Version de Panetius: Et dans celles qu'il avoit faites des Oraisons de Demosthéne, \& d'Esquinés ${ }^{65}$, il dit qu'il a travaillé non pas en Interprete, mais en Orateur; qui est la même chose que j’ay à dire des Dialogues de Lucien; quoy que je ne me sois pas donné une égale liberté par tout. Il y a beaucoup d'endroits que j'ay tra-[p. 8 r.]-duits de mot à mot, pour le moins autant qu'on le peut faire dans une Traduction élegante ${ }^{66}$ : Il y en a aussi où j'ay consideré plutôt ce qu'il faloit dire, ou ce que je pouvois dire que ce qu'il avoit dit à l'exemple de Virgile dans ceux qu'il a pris d'Homere \& de Theocrite. Mais je me suis resserré presque par tout, sans descendre dans le particulier, qui n'est plus de ce tems-cy. Je sçay bien pourtant que cela ne plaîra pas à tout le monde, \& principalement à ceux qui sont idolâtres de toutes les paroles, $\&$ de toutes les pensées des Anciens, \& qui ne croyent pas qu'un Ouvrage soit bon, dont l'Auteur est encore en vie. Car ces sortes de gens-là crieront comme ils fasoient du tems de Terence.

\section{Contaminari non decere Fabulas,}

Qu'il ne faut point corrompre son Auteur, ni rien alterer de son sujet: mais je leur répondray avec luy,

Faciunt nae intelligen

do, ut nihil intelligant,

\footnotetext{
${ }^{64} \mathrm{Na}$ margem esquerda: Sumptas ac versas de Graecis, lib. 2. cap. 23.

${ }^{65} \mathrm{Na}$ margem direita: Pro corona.

${ }^{66} \mathrm{Na}$ margem direita: Partim reliquit, alia expressit, Ec. Quod Graecum quidem mire quam suave est, verti autem neque potuit, neque debuit, A. Gell. 1. 9. с. 9.
} 
Qui cum hunc accusant, Naevium, Plautum,

Ennium

Accusant, quos hic noster authores habet

[p. 8 v.] Quorum aemulari exoptat negligentiam

Potius, quam istorum obscuram diligentiam.

Que cet obscuram diligentiam dit bien le defaut de ces Traductions scrupuleuses, dont il faut lire l'Original pour entendre la Version!

Voilà, Monsieur, ce que j'avois à dire pour ma defense (...).

Vôtre tres-humble \& tres-obeïssant serviteur,

[N. Perrot] D'A Blan Court

\section{Anexo 2}

Confronto de traduções

\subsection{Lúcio e Palestra (Lúcio ou o asno 8-9)}

\begin{tabular}{|c|c|}
\hline Autor & Texto \\
\hline Luciano & 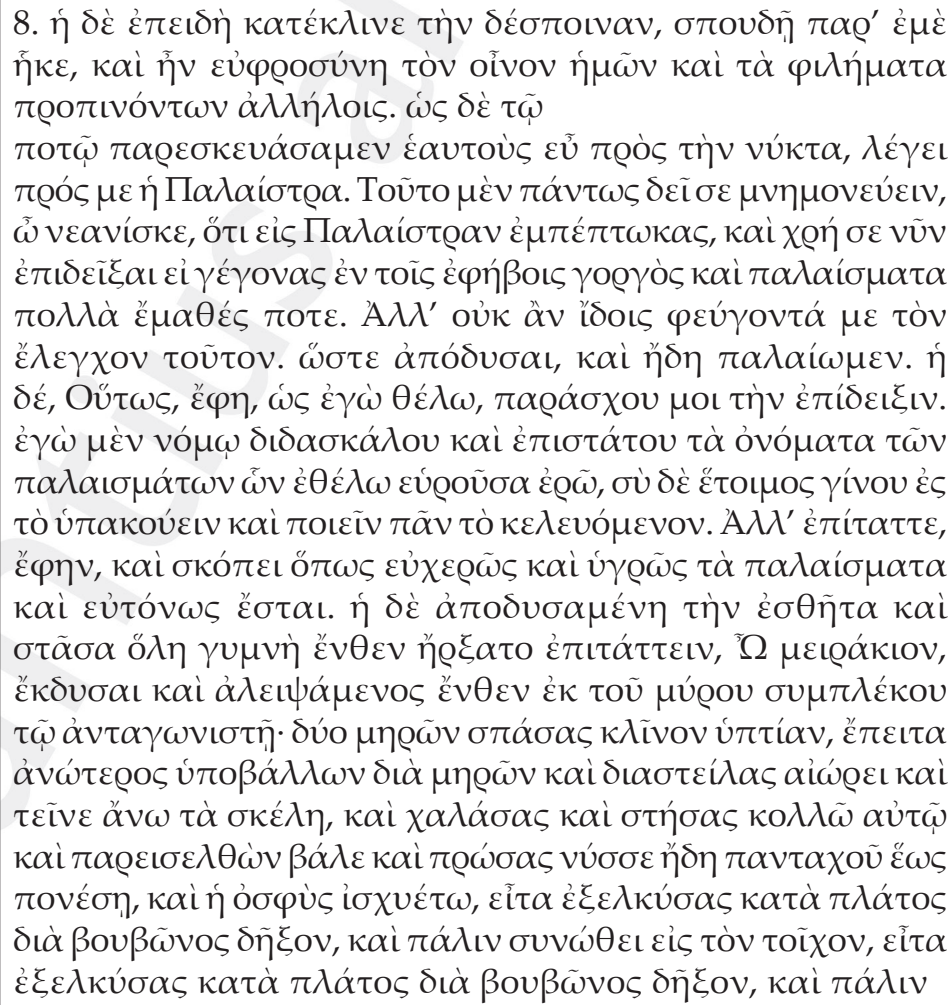 \\
\hline
\end{tabular}




\begin{tabular}{|c|c|c|}
\hline & \multicolumn{2}{|c|}{ 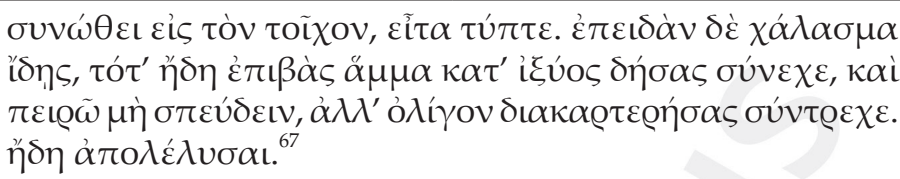 } \\
\hline Mangueijo & $\begin{array}{l}\text { 8. Assim que deixou a patroa } \\
\text { deitada, a rapariga apressou- } \\
\text { se a vir ter comigo; foi uma } \\
\text { alegria - nós a dedicarmos } \\
\text { um ao outro vinho e beijos. Já } \\
\text { bem atestados de bebida para } \\
\text { toda a noite, diz-me Palestra: } \\
\text { "Meu menino, há uma coisa } \\
\text { que deves ter sempre em } \\
\text { mente: que calhaste com uma... } \\
\text { Palestra; }{ }^{18} \text { pois bem: agora há }\end{array}$ & $\begin{array}{l}\text { 18. Notas no pé de página: } 18 . \\
\text { Não esquecer o significado do } \\
\text { nome Palestra: "luta". Começa } \\
\text { aqui uma cena de luta... erótica, } \\
\text { pontuada de vocabulário } \\
\text { técnico, que, para o leitor } \\
\text { antigo, era de compreensão } \\
\text { imediata. }\end{array}$ \\
\hline
\end{tabular}

${ }^{67}$ Observe-se que, após os exercícios reproduzidos acima, tem início uma nova rodada, em que Lúcio continua a se comportar como aluno e Palestra a instruílo, numa refrega que ocupa ainda todo o parágrafo 10 do texto. $\mathrm{Na}$ tradução de Magueijo: Então eu, que havia executado facilmente todas as ordens, assim que a sessão terminou, volto-me para Palestra e digo, sorrindo: "Ó mestra, já vês com que prontidão e docilidade me desempenhei dos exercícios; no entanto, pensa lá se não dirigiste incorretamente os exercícios, pois mandavas fazer um logo a seguir ao outro...” E ela, dando-me um tabefe, disse: "Mas que aluno tão tagarela que eu arranjei; vê lá mas é que não apanhes mais pancada, caso executes golpes diferentes dos que te são ordenados”. E dizendo isto, levanta-se, compõese e diz: "Agora é que vais demonstrar se és um lutador jovem e vigoroso, se sabes realmente lutar e executar os exercícios [de luta] no solo". E caindo de joelhos na cama, disse: "Vamos, lutador, aqui tens a arena: brande a arma em riste, avança, entra a fundo! Como vês, a adversária está desarmada: é de aproveitar. Antes de mais, e como é lógico, cinge-a pela cintura; depois dobra-a, chega-te bem a ela, mantém-na [apertadinha], sem deixar qualquer espaço [entre vós]. E se ela começar a ficar murcha, ergue-a sem demora, muda-a para posição mais elevada, baixa a cabeça e excita-a; mas vê lá não te retires sem to ordenarem; depois dobra-a bem em arco e ergue-a no ar; agora, projecta-a no solo e prossegue a... incursão, [vamos!], mexe-te. Finalmente, larga-a, que a tua adversária está por terra, alquebrada e toda alagada de suor". Então eu, com uma sonora gargalhada, disse: "Pois agora, mestra, também eu quero mandar uns quantos exercícios; é a tua vez de obedecer: salta [da cama] e senta-te [aqui]; depois, deita-me água nas mãos, unta-me com o resto [do óleo], vai limpar-te e [finalmente], por Hércules!, aconchega-me e mete-me na cama". 11. Nestes prazeres e jogos "atléticos" continuámos [por vários dias] a travar "combates" nocturnos, com coroações [e tudo] - o que fazíamos com requintes de sensualidade, a ponto de me esquecer completamente da viagem a Larissa (Luciano, [1992], p. 43-47). 


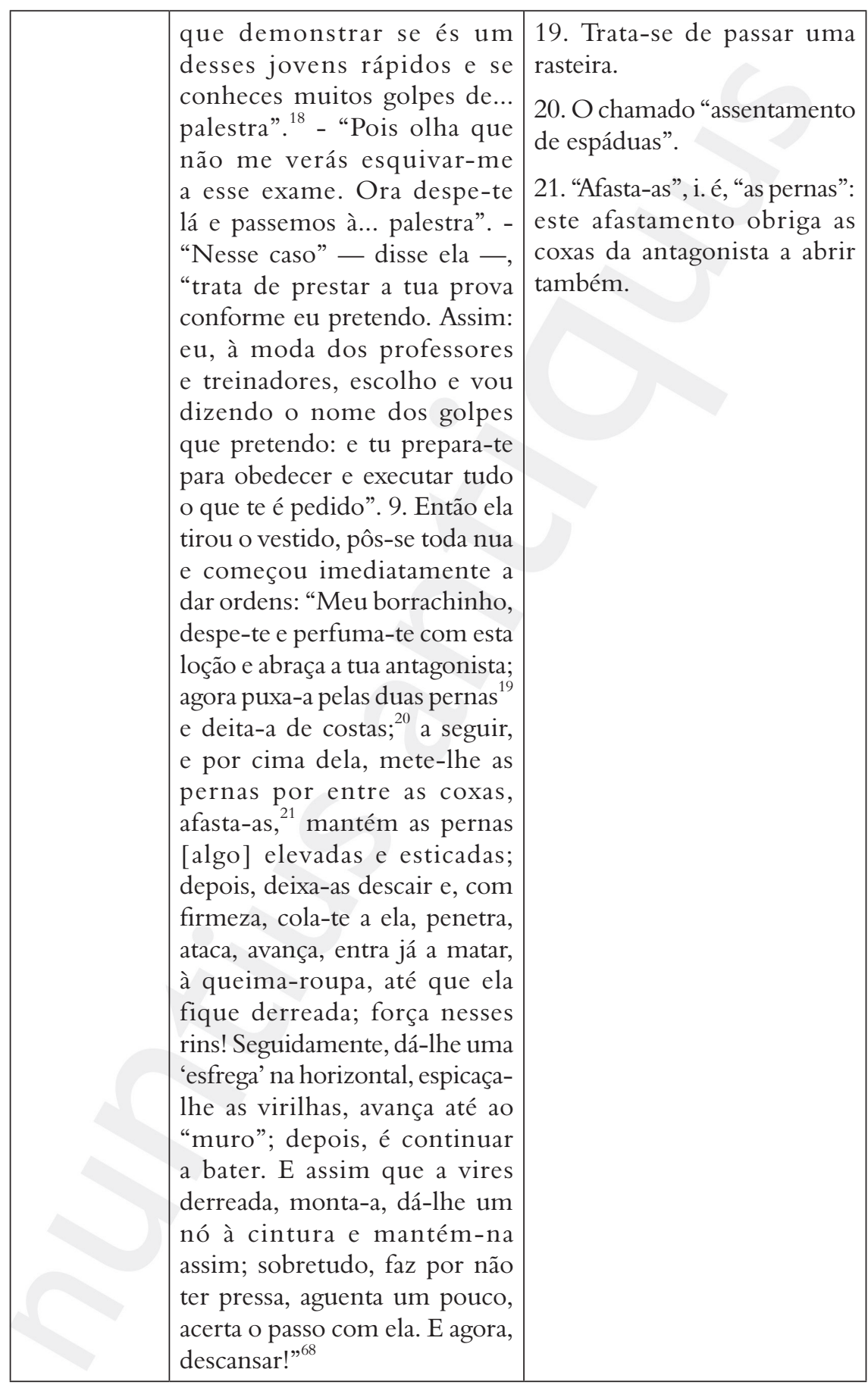

$\overline{{ }^{68} \text { Luciano, [1992], p. } 41-43 .}$ 


\begin{tabular}{|c|c|c|}
\hline D'Ablancourt & $\begin{array}{l}\text { Si tôt qu'elle eut couché sa maîtrasse, } \\
\text { elle me vint trouver, \& nous nous mîmes } \\
\text { à faire collation, \& à nous porter force } \\
\text { santez \& force baisers, \& goûter les } \\
\text { prémices de l'amour. On verra bien-tôt, } \\
\text { dit elle, si tu sçais aussi bien faire que } \\
\text { dire: car je m'apelle Palestre, `\& n'ay } \\
\text { point encore trouvé d'Athléte qui m'a } \\
\text { vaincuë à la lûte. Commej' eus accepté le } \\
\text { combat, elle se deshabille, \& me dit que le } \\
\text { champ estoit ouvert à ma valeur. + Après } \\
\text { quelques tours d'escrime, où chacun } \\
\text { tâcha de montrer ce qu'il sçavoit faire, } \\
\text { nous remîmes la partie au lendemain; \& } \\
\text { je pus tant de plaisir à ce petit exercice, } \\
\text { que j'en oubliay presque le sujet de mon } \\
\text { voyage (vol. II, p. 45). }\end{array}$ & $\begin{array}{l}\text { Notas à margem } \\
\text { direita:^Lûte+ }+ \text { Il y } \\
\text { a ici un passage de } \\
\text { saletez retranchée }\end{array}$ \\
\hline Baudoin & $\begin{array}{l}\text { Aussi-tost qu'Hipparque fut de } \\
\text { retour nous lauasmes nos mains, \& } \\
\text { commençasmes notre repas (...). Nous } \\
\text { commençasmes à nous mignarder \& } \\
\text { entrebaiser, \& prismes vn breuuage pour } \\
\text { nous preparer à la nuict. (...) En mesme } \\
\text { temps elle meit bas sa robbe, \& me dit; } \\
\text { Depouille toy, compagnon, \& ayant pris } \\
\text { de cet vnguent entre en lyce auec ta } \\
\text { guerriere, joignant ta cuisse à la sienne. } \\
\text { Sus, couche moy à l' envers, gaigne le } \\
\text { dessus, \& tandis que ie leueray les cuisses, } \\
\text { appuye toy sur elles; puis frappe de toutes } \\
\text { parts, \& lance ton dard iusqu' à ce que tu } \\
\text { sois las, \& que tes reins ayent mis fin à } \\
\text { un si bel exercice. Retire-le au large, \& } \\
\text { le rejoincts derechef, puis refrappe plus } \\
\text { fort en poursuiuant iusqu' à ce que tuayes } \\
\text { repoussé ton adversaire pres du mur. }{ }^{6}\end{array}$ & \\
\hline
\end{tabular}

${ }^{69}$ Lucian, 1613, p. 303v.-304r. 


\subsection{Lúcio transformado em asno e a mulher apaixonada (Lúcio ou o asno 51)}

\begin{tabular}{|c|c|}
\hline Luc & 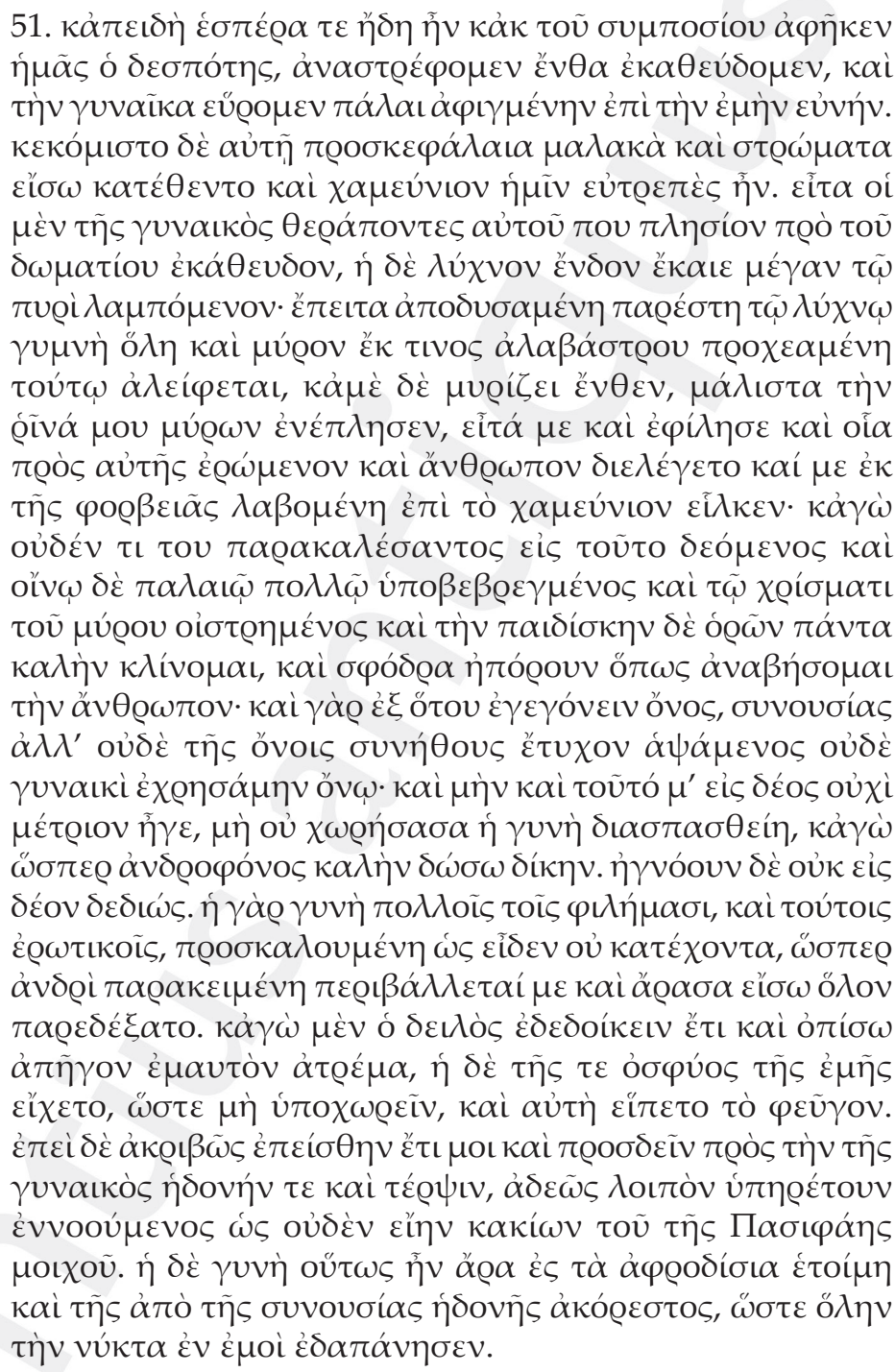 \\
\hline Vide & $\begin{array}{l}\text { Como já era de noite e o nosso amo nos tivesse dado licença de sair } \\
\text { da sala de jantar, retirámo-nos para o quarto onde costumávamos } \\
\text { dormir, e demos com a mulher, que já tinha chegado há muito e } \\
\text { estava à beira da minha cama; tinham-lhe trazido uns travesseiros } \\
\text { fofos e posto cobertores; enfim, havia uma cama no chão, preparada } \\
\text { para nós. Depois, os criados da mulher foram dormir para um sítio } \\
\text { próximo, em frente do quarto, enquanto ela acendia uma candeia }\end{array}$ \\
\hline
\end{tabular}




\begin{tabular}{|c|c|}
\hline & $\begin{array}{l}\text { enorme, que brilhava como uma fogueira. Em seguida, } \\
\text { despiu-se e, assim toda nua, aproximou-se da candeia, deitou } \\
\text { perfume de um frasquinho de alabastro, untou-se com ele e } \\
\text { perfumou-me também a mim, embebendo-me especialmente } \\
\text { o focinho; depois beijou-me, pôs-e a falar comigo como se } \\
\text { fosse seu amante homem, pegou-me pela arreata e puxou- } \\
\text { me para a cama no chão. E eu, que [aliás] não precisava que } \\
\text { ninguém me convidasse para a função, que, [além disso], já } \\
\text { estava um tanto ou quanto "pingado" com grande quantidade } \\
\text { de vinho velho, e, [para mais], excitado pela esfregadela do } \\
\text { perfume, e, [finalmente], perante uma "garota" toda boa, } \\
\text { baixo-me... mas [o caso é que] estava seriamente embaraçado } \\
\text { com a forma de "montar" a criatura. É que, realmente, desde } \\
\text { que estava transformado em burro, nunca me acontecera } \\
\text { de ter um contacto habitual com burros, e muito menos ter } \\
\text { relações íntimas com uma burra. Além disso, uma coisa me } \\
\text { causava um receio nada pequeno: que a mulher, por falta de } \\
\text { "espaço", ficasse desfeita e eu viesse a ser exemplarmente } \\
\text { punido por homicídio. Não sabia eu que esse era um receio } \\
\text { sem fundamento, pois a mulher provocava-me com muitos } \\
\text { beijos, por sinal bem eróticos; e assim que viu que eu já não } \\
\text { tinha mão em mim, deita-se a meu lado como se eu fosse um } \\
\text { homem, abraça-me, introduz [a "coisa"] e recebe-a em pleno. } \\
\text { E eu, coitado, ainda receoso, tentava retirar-me suavemente, } \\
\text { mas a fulana atracou-se-me [com tanta força] ao lombo, que } \\
\text { eu não podia retrair-me: ela mesma ia atrás do "fugitivo". } \\
\text { Quando, enfim, me convenci completamente a colaborar no } \\
\text { prazer e na satisfação da mulher, a partir daí, comecei a "aviá- } \\
\text { la" sem meias medidas e tendo para comigo que não ficava a } \\
\text { dever nada ao amante de Pasífae. Mas o facto é que a mulher } \\
\text { se revelou tão propensa às coisas do amor e tão insaciável nos } \\
\text { prazeres do coito, que gastou toda a noite comigo (p. 135-139). }\end{array}$ \\
\hline Dislonsart & $\begin{array}{l}\text { Au retour du souper nous la trouvâmes qui avoit fait dresser } \\
\text { un lit par terre, pour elle \& pour moi, au lieu où j'avois } \\
\text { acoûtumé de coucher, avec des beaux tapis \& force quarteaux, } \\
\text { pour estre plus molement \& plus delicieusement. Au milieu } \\
\text { de la chambre estoit une lampe d'argent, à la lueur de laquelle } \\
\text { elle se frôta \& moy aussi d'une huile tres-precieuse; puis } \\
\text { m'embrassant me traîna par le cou sur le lict, avec des parôles } \\
\text { \& des caresses, comme si j'eusse esté son galant. Je ne me } \\
\text { fis pas beaucoup prier, parce qu'elle estoit belle, \& que je } \\
\text { me portois fort bien: mais comme je n'avois point caressé } \\
\text { de femmes depuis ma metamorfose, je craignois de la tüer, } \\
\text { \& qu'on ne me punît aprés comme un homicide. A la fin }\end{array}$ \\
\hline
\end{tabular}




\begin{tabular}{|l|l|}
\hline & $\begin{array}{l}\text { enhardy, par l'exemple de Pasifaé, qui avoit bien aimé un } \\
\text { taureau, je me mis en devoir de la satisfaire, \& trouvay que } \\
\text { c'estoit à grand tort que j'avoit eu cette frayeur (p. } 56 \text { r.). }\end{array}$ \\
\hline Baudoin & $\begin{array}{l}\text { Moy qui n'auois besoin d'vn tiers pour m'animer à ce combat, } \\
\text { ie m'en allay librement où me conduisoit cette femme, laquelle } \\
\text { respandit sur moi de bon vin vieil. L'odeurs de l'vnguent, \& la } \\
\text { beauté de la femme me mirent fort en humeur; mais i'estois } \\
\text { en doute de quelle façon i'habiterois auec elle, car depuis le } \\
\text { temps que i'estois asne, ie n'auois iamais monté sur asnesse. }\end{array}$ \\
$\begin{array}{l}\text { D'ailleurs, i'auois belle peur de fendre \& creuser ceste femme, } \\
\text { \& d'en estre à bon droit puny comme meurtrier. Neant-moins } \\
\text { toutes ces considerations estoient vaines: Car apres que la } \\
\text { femme m'eust prouoqué par plusieurs baisers amoureux, \& } \\
\text { qu'elle me sentit prest à l'ouurage, elle m'embrassa comme vn } \\
\text { homme qui eust esté couché sur elle, \& sousleuant le derriere, } \\
\text { reçeut mon membre tout entier. Ie me reculois en arriere de } \\
\text { peur que i'auois de luy nuire, mais elle me serroit toujours } \\
\text { les fesses, \& m'attiroit à soy sans beaucoup s'en destourner } \\
\text { (p. } 313 \text { v.). }\end{array}$ \\
\hline
\end{tabular}

\subsection{Lúcio de novo na forma humana e a mulher apaixonada (Lúcio ou o asno 56)}

\begin{tabular}{|c|c|c|c|}
\hline & ijo & 'Ablancourt & doin \\
\hline 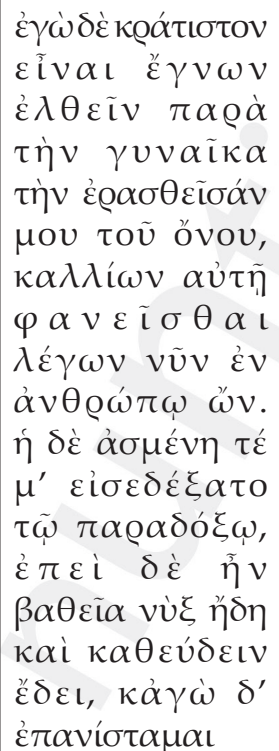 & $\begin{array}{l}\text { fazia ter } \\
\text { dormir, } \\
\text { me e, } \\
\text { fazer "g] } \\
\text { dispo-m } \\
\text { me de p } \\
\text { [diante } \\
\text { pressup } \\
\text { que ass } \\
\text { é], por } \\
\text { compara } \\
\text { burro, a } \\
\text { lhe agra } \\
\text { porém, a } \\
\text { eu tin }\end{array}$ & $\begin{array}{l}\text { Mais il arriva tout } \\
\text { le contraire; car } \\
\text { je recônus de la } \\
\text { froideur dans } \\
\text { son entretien, } \\
\text { que je ne sceus } \\
\text { à quoy atrribuër, } \\
\text { si ce n'estoit à } \\
\text { quelque avantage } \\
\text { que j'avois perdu. } \\
\text { Comme je luy } \\
\text { em demandois } \\
\text { la cause, elle me } \\
\text { dit de fort bonne } \\
\text { grace, qu'elle } \\
\text { voyoit bien que } \\
\text { son amour n'avoit } \\
\text { esté qu'un effet }\end{array}$ & $\begin{array}{l}\text { Quand l'heure } \\
\text { de se coucher } \\
\text { fut venuë, ie } \\
\text { despouilllay mes } \\
\text { habits, \& me tins là } \\
\text { debout tout nud, } \\
\text { m'offrant à faire } \\
\text { plaisir à la femme, } \\
\text { laquelle au lieu } \\
\text { d'asne m'auoit } \\
\text { pres d'elle en la } \\
\text { forme d'homme. } \\
\text { Mais lors que me } \\
\text { voyant nud, elle } \\
\text { s'apperçeut que } \\
\text { tout y estoit d'vn } \\
\text { homme. Sors moy } \\
\text { de ceans, meschant }\end{array}$ \\
\hline
\end{tabular}




\begin{tabular}{|c|c|c|c|}
\hline 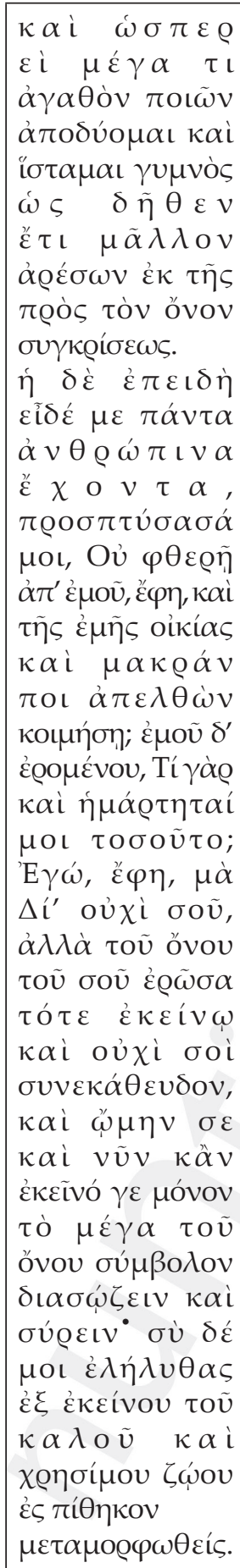 & $\begin{array}{l}\text { escarrou-me na } \\
\text { cara, dizendo: } \\
\text { "Raios te partam! } \\
\text { Sai de ao pé de } \\
\text { mim e de minha } \\
\text { casa e vai dormir } \\
\text { para bem longe } \\
\text { daqui!" E tendo- } \\
\text { lhe perguntado: } \\
\text { "Mas que ofensa } \\
\text { tão grande te fiz } \\
\text { eu?", respondeu: } \\
\text { "É que, por Zeus!, } \\
\text { que eu amava não } \\
\text { era a tua pessoa, } \\
\text { mas sim o burro } \\
\text { que tu eras; com } \\
\text { esse, e não contigo, } \\
\text { é que eu dormia; } \\
\text { cuidava que tu } \\
\text { ainda tivesses } \\
\text { cons e rvado e } \\
\text { trouxesses contigo } \\
\text { pelo menos aquele } \\
\text { singular e enorme } \\
\text { símbolo do burro, } \\
\text { mas, em vez disso, } \\
\text { apareces-me aqui } \\
\text { feito macaco, tu } \\
\text { que eras aquele } \\
\text { tão lindo e útil } \\
\text { animal" (p. 149). }\end{array}$ & $\begin{array}{l}\text { de la curiosité, } \\
\text { parce que'elle } \\
\text { n'avoit plus la } \\
\text { même passion } \\
\text { pour moy, } \\
\text { maintenant que } \\
\text { j'estois homme. } \\
\text { Je retournay donc } \\
\text { au logis tout } \\
\text { honteux... (p. } 57 \\
\text { v.-58 r.) }\end{array}$ & $\begin{array}{l}\text { (me dit-elle en } \\
\text { crachant contre } \\
\text { moy) Va-t'en d'icy } \\
\text { augibet, \& cherche } \\
\text { a dormir ailleurs. } \\
\text { Comme ie luy } \\
\text { e us de mandé, } \\
\text { qu e lle fa ute } \\
\text { auois-je commise, } \\
\text { \& pourquoi me } \\
\text { chassoit-elle ainsi? } \\
\text { C'est parce que ie } \\
\text { ne t'ay pas aimé, } \\
\text { mes dist-elle, mais } \\
\text { bien l'asne auec } \\
\text { lequel i'ay couché. } \\
\text { Ie croyois que tu } \\
\text { n'eusses posé que } \\
\text { la forme d'asne, } \\
\text { te reseruant ce } \\
\text { que i'auois chery } \\
\text { de plus excellent } \\
\text { en toy: Mais a ce } \\
\text { que ie vois tu a } \\
\text { perdu ce qui seul } \\
\text { sembloit estre vtile } \\
\text { à vn asne, \& as esté } \\
\text { transmué en ie ne } \\
\text { sçay quel marmor } \\
\text { (p. } 315 \text { r.). }\end{array}$ \\
\hline
\end{tabular}




\subsection{Os marinheiros-navio (Narrativas verdadeiras 45)}

\begin{tabular}{|c|c|c|c|}
\hline Luciano & Moosburger & D'Ablancourt & Baudoin \\
\hline 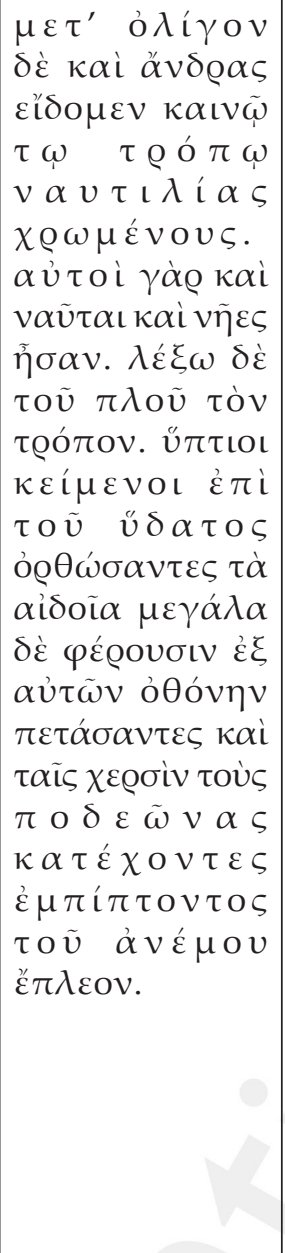 & $\begin{array}{l}\text { Pouco depois } \\
\text { avistamos também } \\
\text { homens, que se } \\
\text { utilizavam de } \\
\text { uma forma de } \\
\text { navegação nova; } \\
\text { pois eles eram ao } \\
\text { mesmo tempo } \\
\text { o marinheiro e } \\
\text { o barco. Direi a } \\
\text { forma com que } \\
\text { n a v e a a m : } \\
\text { estavam deitados } \\
\text { de costas sobre } \\
\text { a água com os } \\
\text { membros sexuais } \\
\text { eretos (e eles os } \\
\text { possuem grandes), } \\
\text { onde ti n ha m } \\
\text { amarrado a vela e } \\
\text { seguravam com } \\
\text { as mãos a ponta, e } \\
\text { navegavam com o } \\
\text { vento a propelir. }\end{array}$ & $\begin{array}{l}\text { Nous vîmes-là de } \\
\text { plaisans nageurs; } \\
\text { c'étoient des } \\
\text { gens couchés } \\
\text { sur le dos avec } \\
\text { un bâton entre } \\
\text { les jambes, qui } \\
\text { servoit comme } \\
\text { de mât, où étoit } \\
\text { attachée une } \\
\text { petite voile qu'ils } \\
\text { conduisoient } \\
\text { avec la main, \& } \\
\text { voguoient ainsi } \\
\text { sur l'océan. }\end{array}$ & $\begin{array}{l}\text { Durant ceste } \\
\text { n a u igat i o n, } \\
\text { nous vismes des } \\
\text { hom mes qui } \\
\text { nauigeoient d'vne } \\
\text { nouuelle façon: } \\
\text { car ils estoient } \\
\text { eux-mesmes les } \\
\text { vaisseaux \& les } \\
\text { nautonniers. Ie } \\
\text { suis contant de } \\
\text { vous en faire le } \\
\text { recit. Ils estoient } \\
\text { estend us sur } \\
\text { l'eau le ventre } \\
\text { contre-mont, \& } \\
\text { auoient l'engin } \\
\text { grand, droict, \& } \\
\text { tendu, auquel ils } \\
\text { attachoient des } \\
\text { voiles. Dauantage, } \\
\text { ils tenoient } \\
\text { les extremitez } \\
\text { des leurs pieds } \\
\text { auec les mains, } \\
\text { \& nauigeoient } \\
\text { de cette façon à } \\
\text { l'ayde duvent qui } \\
\text { les poussoit (p. } \\
212 \text { ). }\end{array}$ \\
\hline
\end{tabular}

${ }^{70}$ Luciano, 2009.

${ }^{71}$ Lucien, 1984, p. 53. 


\subsection{Como deve ser o historiador (outras traduções de Como se deve escrever a história 41)}

\begin{tabular}{|c|c|}
\hline Autor & Texto \\
\hline Baudoin & $\begin{array}{l}\text { Ie veux donc que le vray Historien ne soit ny } \\
\text { timide, ny corruptible, ains, libre, hardy, amy } \\
\text { de la verité; \&, comme dit le Comique, qu'il } \\
\text { nomme la figue vne figue, \& le hoyau, vn } \\
\text { hoyau: Qu'il ne cede rien ny par amitié ny par } \\
\text { haine: qu'il n'espargne personne: que la honte } \\
\text { ne le fasse iamais rougir: que la raison \& la } \\
\text { iustice ayent plus de force sur luy, que non pas } \\
\text { le mensonge: Bref, qu'il soit estranger en ses } \\
\text { propres liures: \& que luy mesme se donne des } \\
\text { loix, sans se rendre esclaue d'autruy, ny sans } \\
\text { considerer ce qui peut plaire à l'vn, \& desplaire } \\
\text { à l'autre (p. } 190 \mathrm{v} \text {.). }\end{array}$ \\
\hline Jacintho de São Miguel & $\begin{array}{l}\text { Tal pois, quanto a mim, seja o historiador: } \\
\text { intrépido, incorrupto, livre, amigo da liberdade } \\
\text { no dizer e da verdade, nomeando (como diz } \\
\text { o cômico) aos figos, figos, ao prato, prato; } \\
\text { não governando-se por ódio nem por amor; } \\
\text { não perdoando ou compadecendo-se; não } \\
\text { envergonhando-se nem respeitando; seja juiz } \\
\text { igual e benévolo para todos até o não dar a } \\
\text { ninguém alguma cousa mais de decente. Nos } \\
\text { livros seja peregrino, sem cidade, sem lei, sem } \\
\text { rei; não considerando o que parecerá a este ou } \\
\text { àquele, mas dizendo o que se fez. }\end{array}$ \\
\hline Manoel de Santo António & $\begin{array}{l}\text { Quanto a mim, o historiador há de ser de tal } \\
\text { condição que nem tema, nem o dobrem dádivas, } \\
\text { livre, amigo de dizer a verdade livremente, } \\
\text { para, como diz o cômico, chamar aos figos, } \\
\text { figos, e escudelha à escudelha; não há de } \\
\text { condescender com o ódio, nem com a afeição, } \\
\text { nem há de perdoar, nem compadecer-se, nem } \\
\text { envergonhar-se, nem render-se a rogos; há de } \\
\text { ser juiz com igualdade e benevolência para } \\
\text { todos, de tal modo que não dê a ninguém mais } \\
\text { do que é justo. Com os livros seja estrangeiro; } \\
\text { não o domine o amor da Pátria; ninguém lhe } \\
\text { dê leis, ninguém o mande; não cuide no que } \\
\text { contentará a este ou àqueloutro, mas conte o } \\
\text { sucedido. }\end{array}$ \\
\hline
\end{tabular}




\begin{tabular}{|l|l|}
\hline Custódio de Oliveira & $\begin{array}{l}\text { Tal seja o meu historiador, sem medo, incapaz } \\
\text { de ser corrompido, livre e amigo da verdade, } \\
\text { e com desembaraço para dizê-la, chamando, } \\
\text { como o cômico, ao figo, figo, ao batel, batel, sem } \\
\text { dar lugar ao ódio ou à amizade; sem perdoar, } \\
\text { ou seja por compaixão, receio ou vergonha; } \\
\text { juiz inteiro e benévolo para todos, para que a } \\
\text { ninguém dê mais do que é justo, sendo nos seus } \\
\text { livros como um estranho, não adido a cidade } \\
\text { alguma, sujeito somente às suas próprias leis e } \\
\text { reconhecendo por único soberano a verdade, } \\
\text { sem considerar o que agradará a este ou àquele, } \\
\text { mas narrando sinceramente os fatos. }\end{array}$ \\
\hline Jacyntho Lins Brandão & $\begin{array}{l}\text { Portanto, assim seja para mim o historiador: sem } \\
\text { medo, incorruptível, livre, amigo da franqueza } \\
\text { e da verdade; como diz o poeta cômico, alguém } \\
\text { que chame os figos de figos e a gamela de } \\
\text { gamela; alguém que não admita nem omita } \\
\text { nada por ódio ou por amizade; que a ninguém } \\
\text { poupe, nem respeite, nem humilhe; que seja } \\
\text { juiz equânime, benevolente com todos a ponto } \\
\text { de não dar a um mais que o devido; estrangeiro } \\
\text { nos livros e apátrida, autônomo, sem rei, não se } \\
\text { preocupando com o que achará este ou aquele, } \\
\text { mas dizendo o que se passou (p. 71). }\end{array}$ \\
\hline
\end{tabular}

2.6. Cortes homéricos (Como se deve escrever a história 7-10): os trechos cortados estão indicados itálico, entre colchetes e numerados

\begin{tabular}{|c|c|}
\hline Luciano & 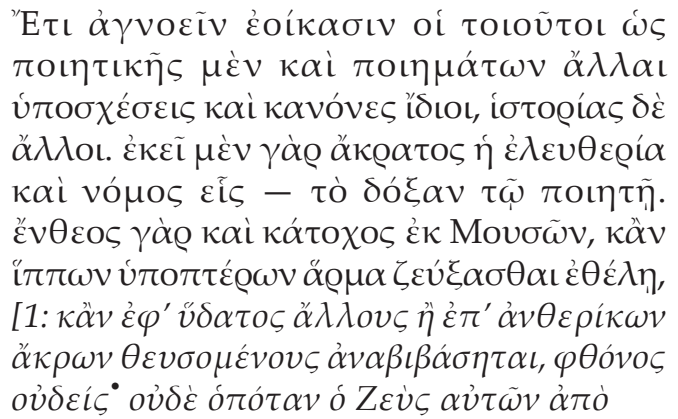 \\
\hline
\end{tabular}

${ }^{72}$ Luciano, 1771, p. 84. 


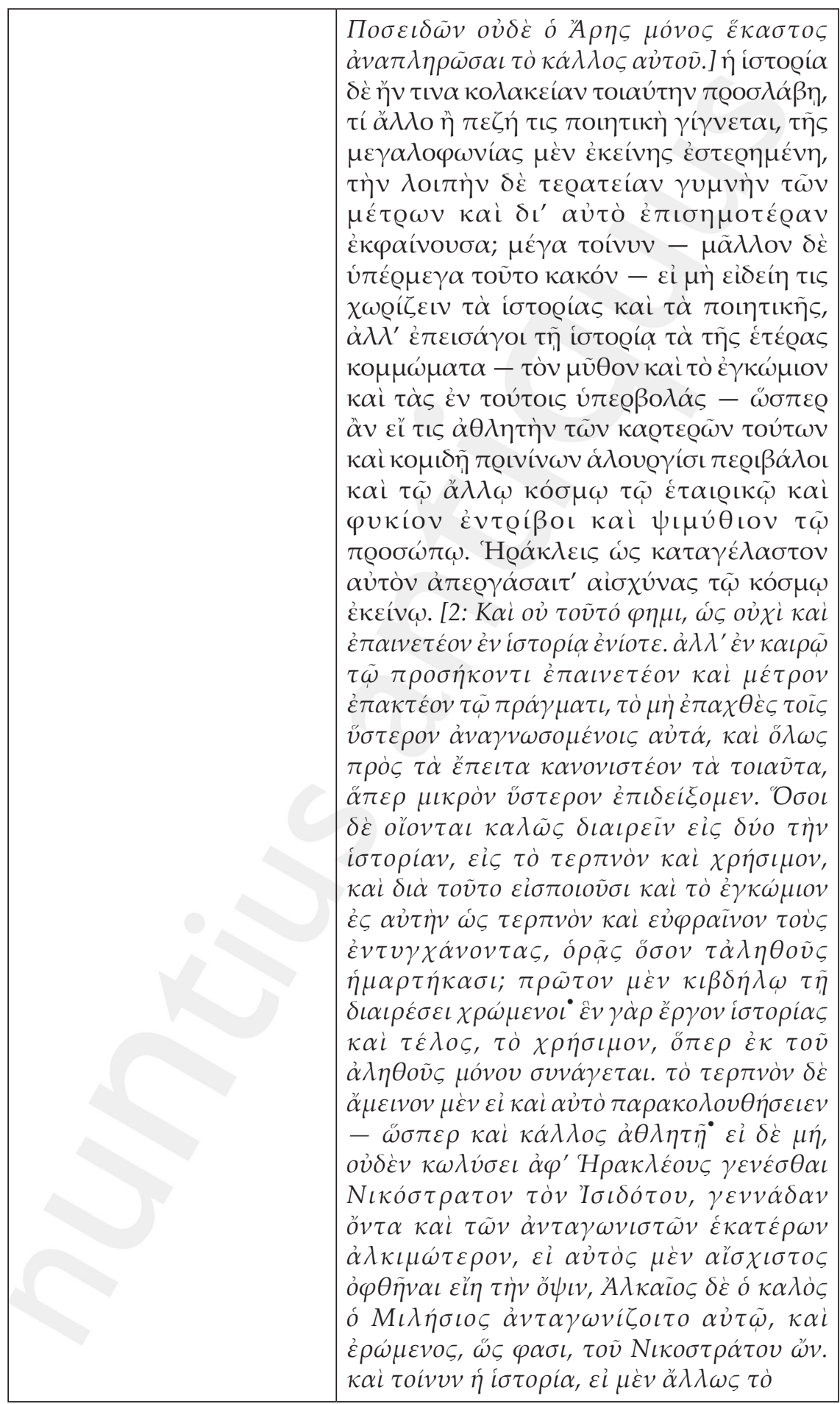




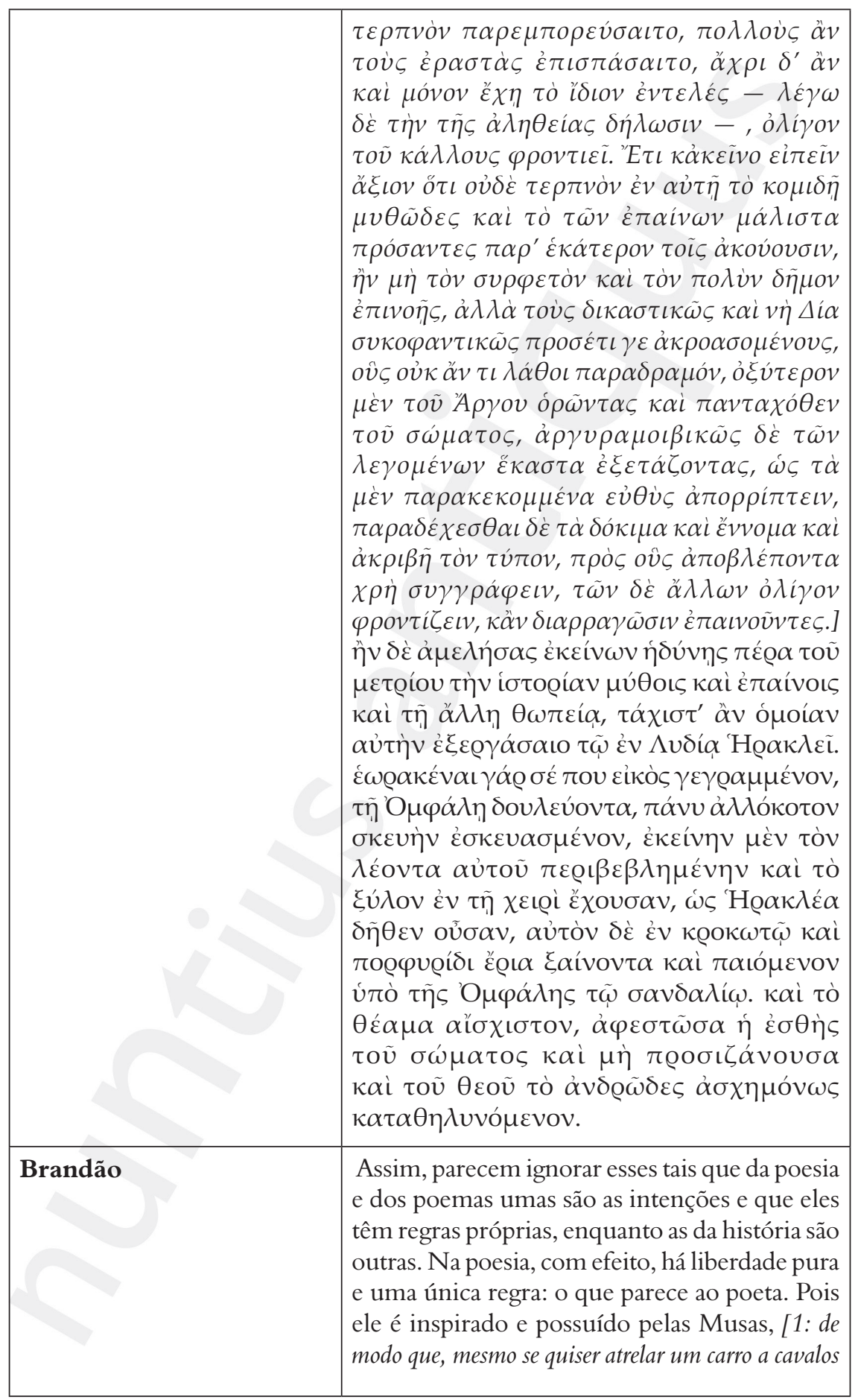




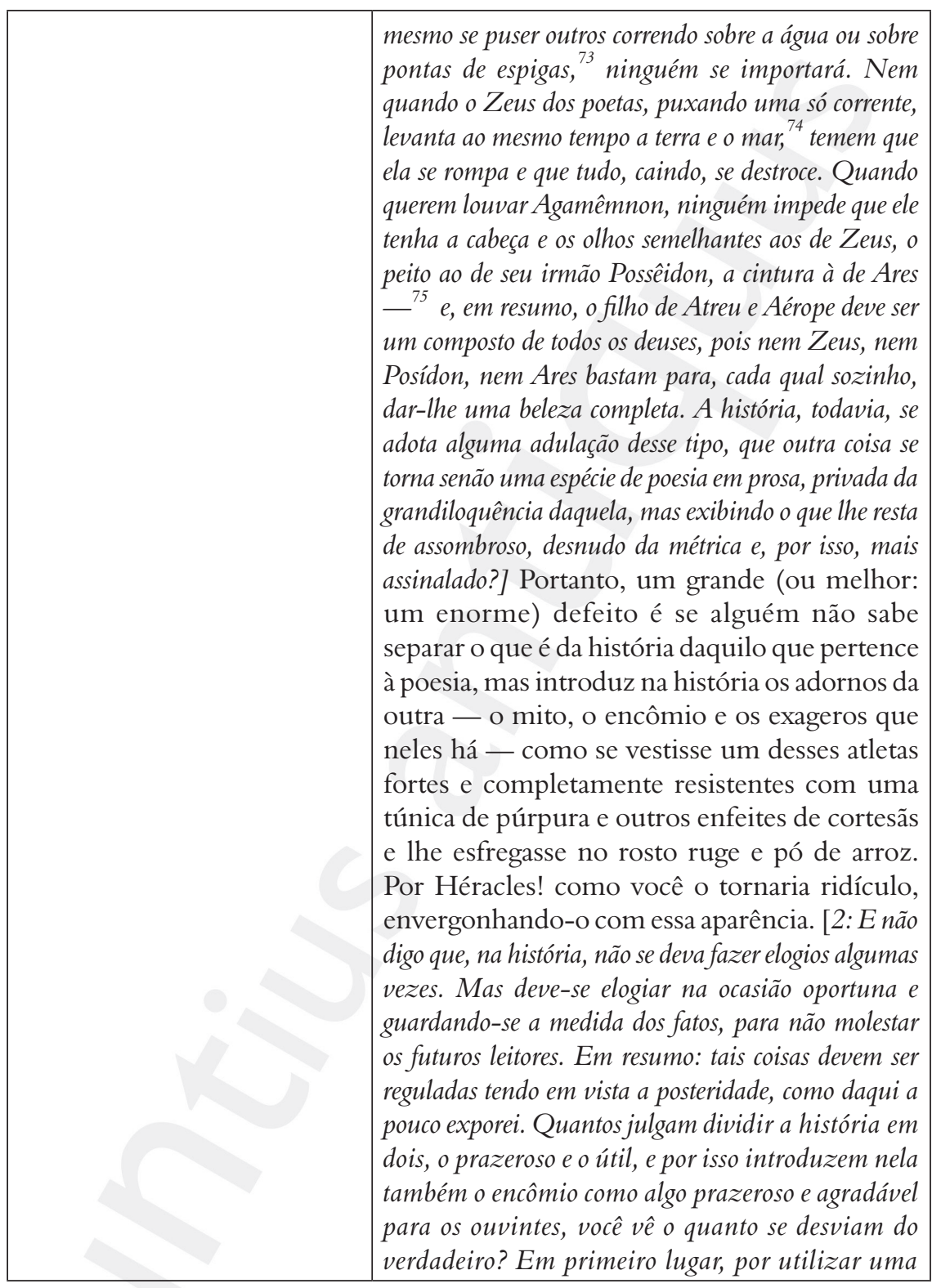

${ }^{73}$ Ilíada XX, 226-229.

${ }^{74}$ Ilíada XX, 226-229.

${ }^{75}$ Ilíada II, 478-479. 


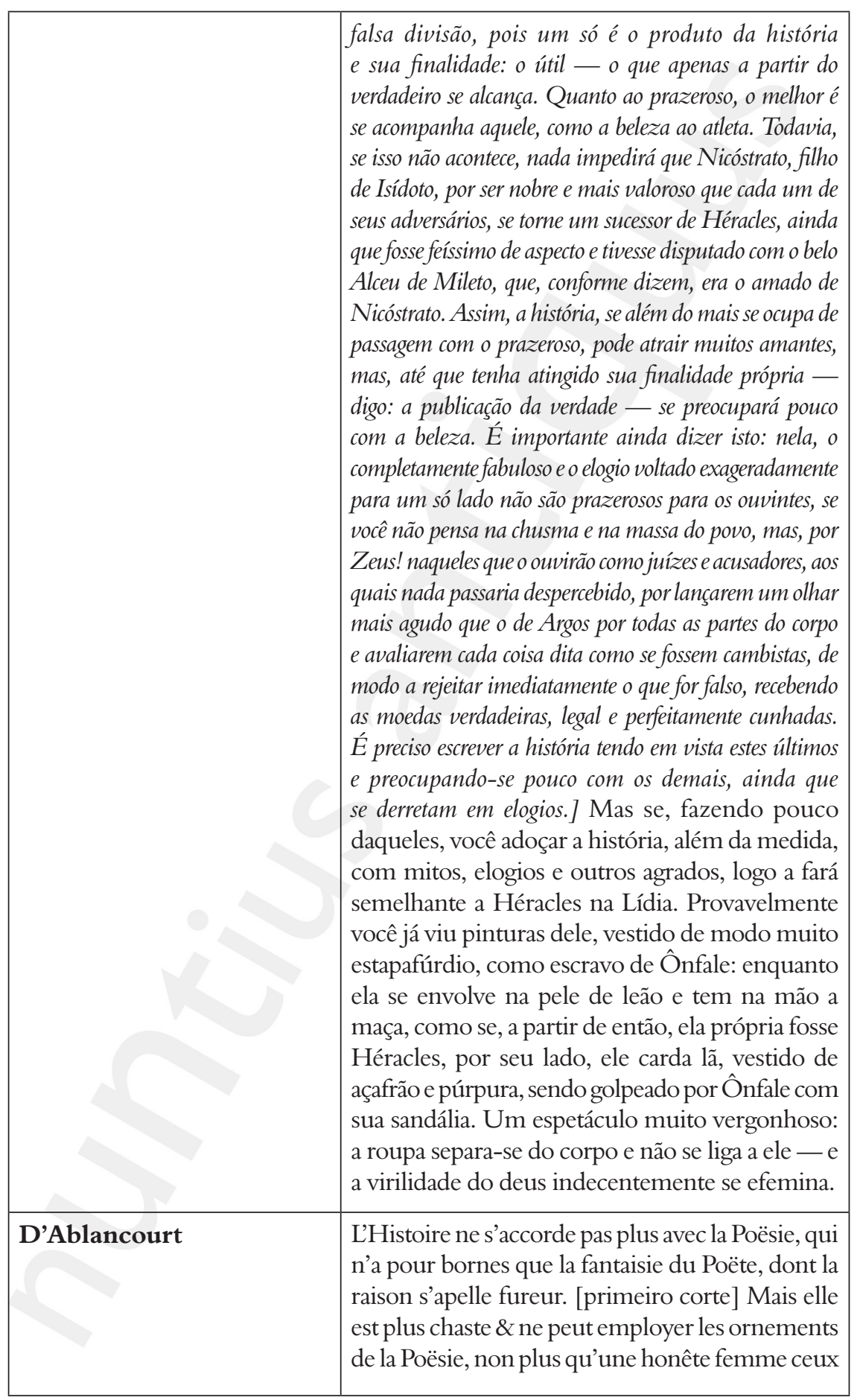




\begin{tabular}{|l|l|}
\hline d'une Courtisane; [segundo corte] d'autant plus, \\
qu'elle n'emprunte pas de secours des Fictions, \\
\& n'a pas les figures, \& les mouvements qui \\
transportent l'âme \& la métent hors de son siege. \\
Si vous y mélez donc trop d'ornements, vous \\
la rendez semblable à Hercule vêtu des habits \\
d'Onfale, qui est la derniere extravagance (p. \\
273-274).
\end{tabular}

